HOW TO GET THE SALAMANDER ACROSS THE ROAD: EXPLORING THE POLICY INTERSECTION OF BIODIVERSITY CONSERVATION AND ROAD PROJECTS IN ONTARIO

\author{
By \\ Joshua Wise \\ B.A. Geography, University of Guelph, 2009 \\ M.E.S. University of Western Ontario, 2010 \\ A Major Research Paper \\ presented to Ryerson University \\ in partial fulfillment of the requirements for the degree of \\ Master of Planning \\ in the program of \\ Urban Development \\ Toronto, Ontario, Canada, 2018
}

(C) Joshua Wise, 2018 


\section{AUTHOR'S DECLARATION}

I hereby declare that I am the sole author of this MRP. This is a true copy of the MRP, including any required final revisions.

I authorize Ryerson University to lend this MRP to other institutions or individuals for the purpose of scholarly research.

I further authorize Ryerson University to reproduce this MRP by photocopying or by other means, in total or part, at the request of other institutions or individuals for the purpose of scholarly research I understand that my MRP may be made electronically available to the public. 


\title{
HOW TO GET THE SALAMANDER ACROSS THE ROAD: EXPLORING THE POLICY INTERSECTION OF BIODIVERSITY CONSERVATION AND ROAD PROJECTS IN ONTARIO
}

\author{
(C) Joshua Wise 2018 \\ Master of Planning \\ in \\ Urban Development \\ Ryerson University
}

\begin{abstract}
Connecting landscapes around roads is an important element in a broader strategy to help protect and recover biodiversity. In regions like southern Ontario and the Greater Golden Horseshoe, growing urban footprints are leading to an expansion of road networks. Road planning and design has historically fragmented natural habitat and created barriers for wildlife movement. The negative impacts of roads can be mitigated through the creation of wildlife crossing structures that enable safe passage of wildlife over or under roads. This Major Research Paper will investigate key Ontario land use and regulatory policies that intersect with both road projects and biodiversity recovery to evaluate their effectiveness in recognizing biodiversity values and enabling the creation of wildlife crossing structures.
\end{abstract}

Key words: landscape connectivity, wildlife crossing, safe passage, biodiversity, conservation, policy, planning, Ontario, Greater Golden Horseshoe 


\section{ACKNOWLEDGEMENTS}

The development of this Major Research Paper was supported by a group of incredible mentors and colleagues. I would like to express my sincere gratitude to Prof. Nina-Marie Lister who supervised this MRP and provided thoughtful guidance and support throughout the process. I am very appreciative of Brenda Caruthers for acting as the second reader for this paper. Brenda's guidance helped to improve the accuracy of the assessment and increase the depth of the evaluation.

Thank you to Dr. Pamela Robinson and Dr. Raktim Mitra for providing feedback during the development of the proposal for this Major Research Paper- and thanks to Pamela for inspiring the title.

I would also like to thank the expert practitioners from across Ontario who participated in interviews: Peter Andrew-McBride, Jackie Charlton, Joe Crowley, Gillian Dagg-Foster, Kari Gunson, Megan Hazell, Andrew Healy, Mandy Karch, Leah Lefler, Rick Levick, April Nix, Terri Rogers, Jackie Scott, Namrata Shrestha, and Brenda Carruthers.

Thank you to Marta Brocki, Program Manager at the Ecological Design Lab and to fellow Graduate Research Assistants Michelle Rowland, Marc Cinq-Mars, and Alyssa Cerbu who helped in organizing and conducting the practitioner interviews.

A special thanks to Lauren and my family for all their support throughout the process of completing this MRP and Master of Planning degree. I hope you all found our many conversations about landscape connectivity as interesting as you made it seem.

The research for this MRP was supported by funding through a Partnership Development Grant of the Social Sciences and Humanities Research Council of Canada (SSHRC), held by Prof. Nina-Marie Lister through the Ecological Design Lab at Ryerson University.

Note, however that the views presented in this paper represent those of the author and do not necessarily reflect those of the aforementioned individuals. 


\section{TABLE OF CONTENTS}

Author's Declaration $\quad$ ii

Abstract iii

Acknowledgements $\quad$ iv

List of figures and tables $\quad$ vi

List of tables vii vil

List of appendices viii

1.0 Introduction 1

1.1 Southern Ontario and the Greater Golden Horseshoe $\quad 1$

1.2 Study rationale 3

1.3 Research question and objectives 3

2.0 Setting the context: literature review and policy overview 4

2.1 Biodiversity decline and conservation responses 4

2.2 Biodiversity commitments and connecting landscapes 13

2.3 Policies at the intersection of road projects and biodiversity recovery in Ontario 17

2.4 Targets, policies, and implementation gap 19

3.0 Methods and methodology 21

3.1 Primary research 21

3.2 Secondary research $\quad 23$

3.3 Policy analysis methodology 23

4.0 Policy analysis $\quad 28$

4.1 Problem statement $\quad 28$

4.2 Criteria evaluated 29

4.3 Policy identification $\quad 32$

4.4 Multi-criteria analysis: comparative matrix $\quad 32$

4.5 Scoring policy effectiveness 38

4.6 Policy evaluation: assessment of relative strengths and weaknesses 42

4.7 Limitations of study $\quad 44$

5.0 Findings and emerging opportunities $\quad 46$

5.1 Findings and recommendations 46

5.2 Emerging opportunity: areas for action 48

5.3 Emerging opportunity: regional connectivity and achieving Canada's Target \#1 49

5.4 Approaching 2020 at the intersection of biodiversity and roads 50

$\begin{array}{ll}\text { Appendices } & 52\end{array}$

$\begin{array}{ll}\text { References } & 59\end{array}$ 


\section{LIST OF FIGURES}

Figure 1: Southern Ontario with 53 physiographic areas identified $\quad 2$

Figure 2: Road density in southern Ontario $\quad 2$

Figure 3: WWF's Global Living Planet Index: Vertebrate Species Abundance 1970-2010 4

Figure 4: Wetland cover in southern Ontario 1800-2002 5

Figure 5: Concentration of Species at Risk richness across Ontario $\quad 6$

Figure 6: Three major interactions of mobile wildlife with roads $\quad 10$

Figure 7: Road length in Ontario 1935-2005 10

Figure 8: Effective Mesh Size in southern Ontario, 2011

Figure 9: Images of examples of wildlife crossing structures in Ontario 12

Figure 10: International, national and provincial targets relevant to landscape connectivity 16

and road projects

Figure 11: Provincial land use plans in the Greater Golden Horseshoe 18

Figure 12: Simplified chart indicating evaluated policy's generalized interaction with 19

development of road projects

Figure 13: Policy analysis methodology 24

Figure 14: Comparison of protected area coverage in G7 countries $\quad 49$

Figure 15: Eastern redback salamander in the Happy Valley Forest, King, Ontario 51 


\section{LIST OF TABLES}

Table 1: Major disciplines and terms related to landscape connectivity

Table 2: Major ecological effects of roads to wildlife

Table 3: Aichi targets and implication for landscape connectivity and road projects 14

Table 4: Relevant 2020 Biodiversity Targets for Canada $\quad 15$

Table 5: Relevant Ontario Biodiversity Strategy Targets 16

Table 6: Ontario expert practitioners interviewed for MRP $\quad 22$

Table 7: Criteria developed to compare and evaluate selected policy $\quad 25$

Table 8: Policies identified for analysis $\quad 26$

Table 9: Policies identified for analysis with sources $\quad 32$

Table 10: Evaluation criteria and categories for comparison 33

Table 11: Comparative matrix $\quad 35$

Table 12: Relative effectiveness of policy approach/application 38

Table 13: Scoring policy effectiveness $\quad 39$ 


\section{LIST OF APPENDICES}

Appendix A: Summary of Safe Passage SSHERC Proposal

Appendix B: Expert Practitioner Interview Guide

Appendix C: Summary of relevant policies identified through practitioner interviews 


\section{HOW TO GET THE SALAMANDER ACROSS THE ROAD: EXPLORING THE POLICY INTERSECTION OF BIODIVERSITY CONSERVATION AND ROAD PROJECTS IN ONTARIO}

\subsection{Introduction}

The loss of biodiversity across Ontario and around the world has reached "crisis" levels (ECO, 2016). Across southern Ontario and the Greater Golden Horseshoe (GGH) region, a dramatic decline in biodiversity -the diversity of life amongst a species, between species and of ecosystems -has largely occurred due to habitat loss and fragmentation associated with expanding human settlements (UN CBD, 1992; Cowie, 2011). As settlements and populations have grown, so too has the road network. Roads have knitted together the land for humans, while simultaneously creating a patchwork of natural habitats isolated between urban areas, farms and other human-uses (Forman et al., 2003).

The loss of biodiversity at a regional-scale affects the functioning of natural ecosystems that support the livability of the region (CBD, 2010; Johnson et al., 2017; OBC, 2011). Roads directly fragment wildlife habitat and create barriers for plant and animal movement, reducing the landscape's natural connectivity (Lister et al., 2015; Hadad, 2015; Beckmann \& Hilty, 2014; Forman et al., 2003). The increase of roads and traditional grey infrastructure decreases landscape resiliency, as regular ecosystem functions (e.g. water flow, pollination, food security, carbon sequestration) are negatively affected by linear interruptions (UN CBD, 2010; Corestine, et al., 2018).

Interventions in the traditional approaches to North American road planning and design can help to reconnect landscapes for wildlife as part of a strategy to recover biodiversity (Hadad, 2015; Environment Canada, 2005). Local and regional connectivity can be improved by integrating wildlife crossing structures designed for mobile terrestrial species (e.g. salamanders, turtles, frogs, mammals) in to road projects (Lister et al., 2015). Policies that prioritize landscape connectivity in road projects can help reduce pressures on biodiversity across southern Ontario and the GGH.

\subsection{Southern Ontario and Greater Golden Horseshoe}

Southern Ontario is the most biologically diverse region of Canada, home to the Mixed-wood Plains ecozone. This region is generally defined as the area to the north of Lake Erie, Lake Ontario and the lower St. Lawrence and south of the Canadian Shield, extending from Windsor to the Ottawa Valley (Figure 1) (Environment Canada, 2014). At the approximate centre of southern Ontario is the GGH, which is home to the region's densest population and road network (Figure 2 \& Figure 11). In the GGH the vast road network cris-crosses a rich diversity of physiographic areas, including the Carolinian Life Zone, Lake Iroquois shoreline, Niagara Escarpment and Oak Ridges Moraine (Environment Canada, 2014).

The Province of Ontario is home to 14.2 million people, with the GGH representing the vast majority of this population with nearly 10 million people living across the region's 32,000 km² (MOF, 2018; Hemson, 2013). The GGH region is projected to continue a high rate of population growth, adding approximately 150,000 people every year till at least 2041 (Hemson, 2013). The magnitude of growth in this region is likely to present challenges associated with increased traffic congestion and demand on the existing road network (MMA, 2017a). This will result in a need for road improvements and additional road projects to connect people and accommodate higher usage. 
Figure 1: Southern Ontario with 53 physiographic areas identified (Environment Canada, 2014)

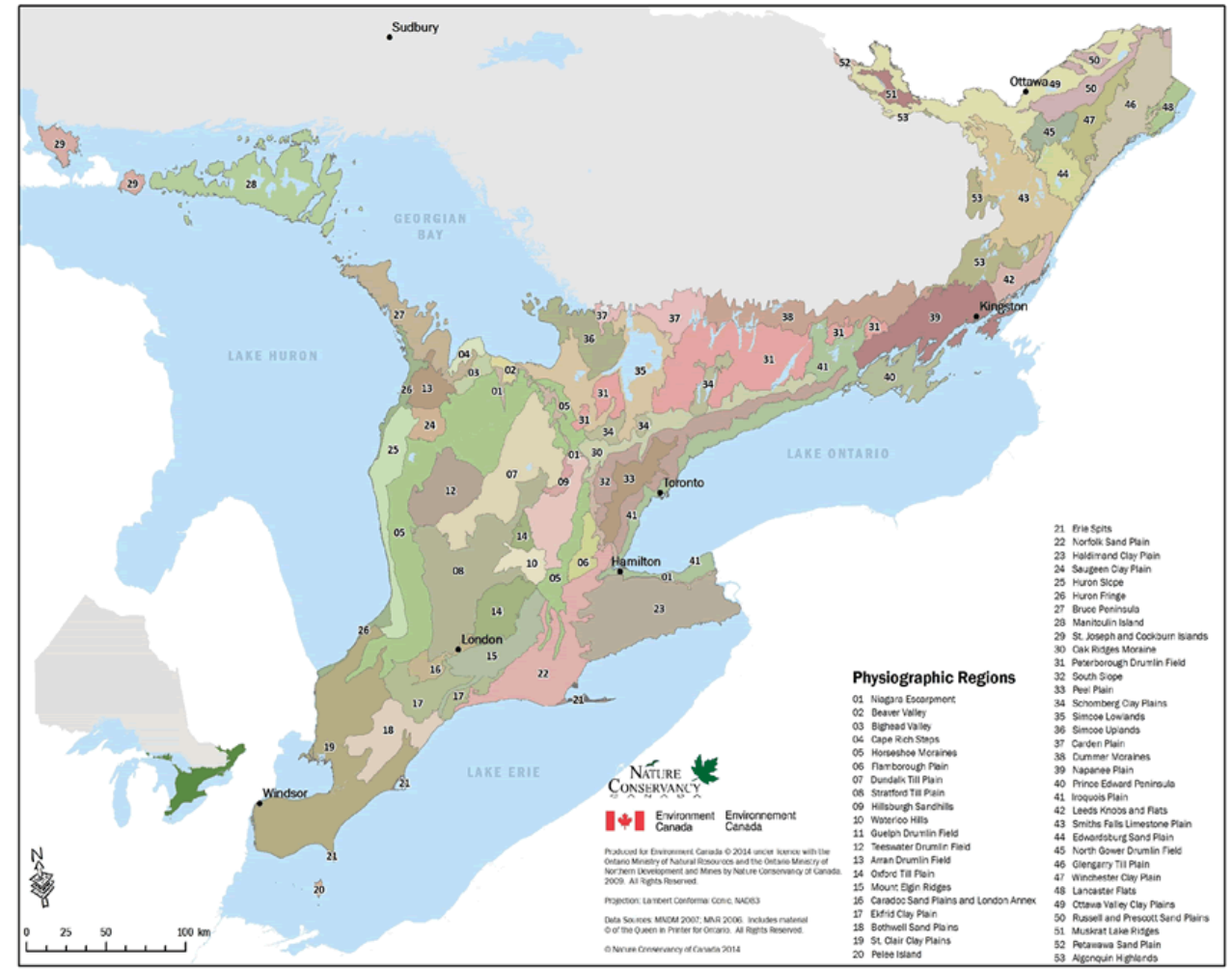

Figure 2: Road density in southern Ontario (OBC, 2015)

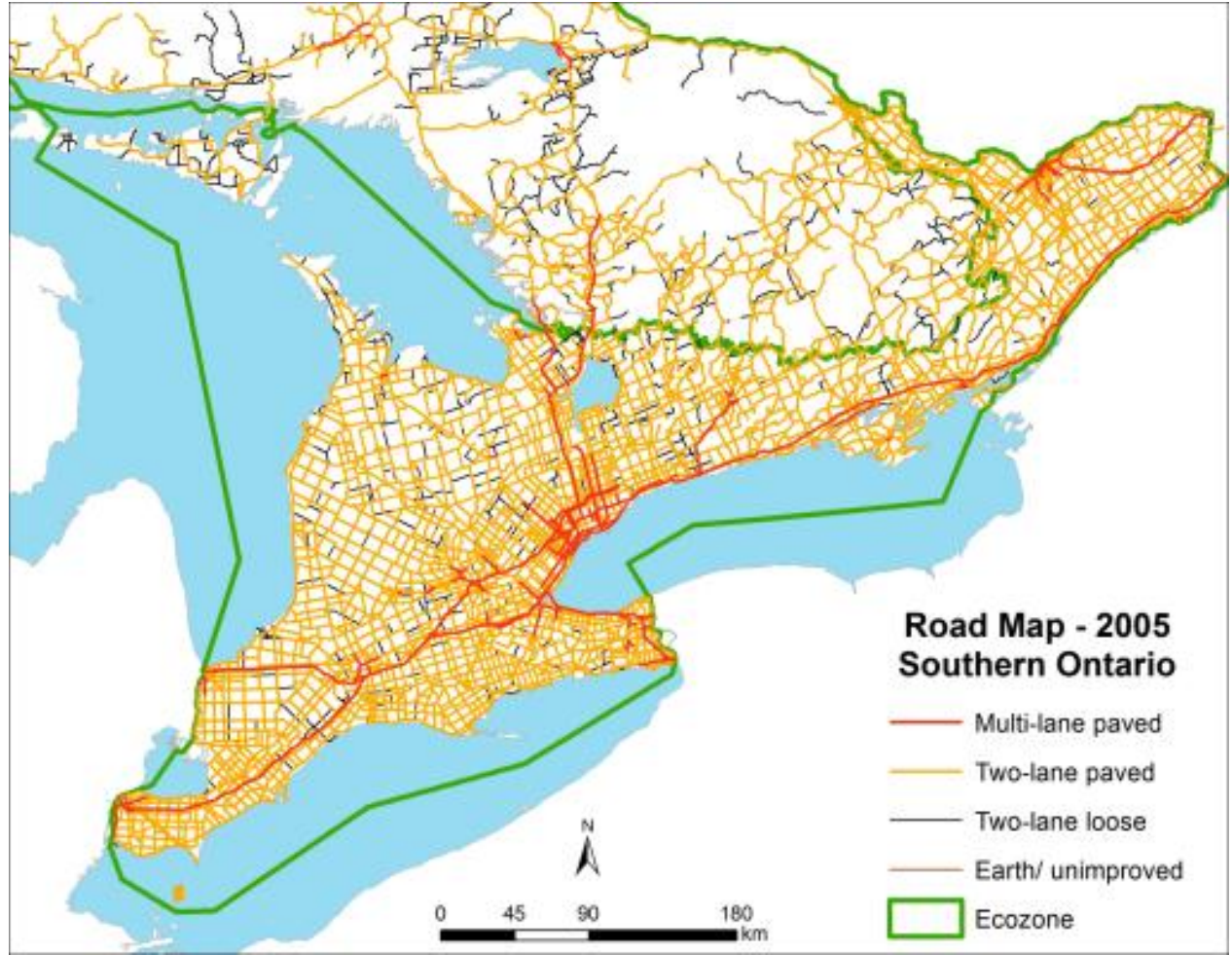




\subsection{Study rationale}

The crisis of biodiversity decline is a formidable modern challenge that is world-wide in scope and will require action on multiple fronts (McGill et al., 2015; OBC, 2011). In southern Ontario and the GGH, habitat fragmentation continues to increase as the region urbanizes and converts natural and agricultural areas into cities and roads.

In Canada, provincial governments hold much of the responsibility when it comes to protecting biodiversity (ECO, 2012). Stemming from the United Nation's Convention on Biological Diversity (UN CBD) is Ontario's Biodiversity Strategy which outlines actions for the Province to implement before 2020 to help address biodiversity decline (CBD, 2000; OBC, 2011). As the 2020 target dates approach it is unclear how effectively provincial policies have addressed conservation issues, including landscape connectivity around roads.

This Major Research Paper (MRP) is intended to add to the building knowledge outlining approaches to better plan urbanizing regions with nature in mind. The impetuous for this MRP stems from a recognition that there is an emerging public policy imperative in southern Ontario and GGH to find new ways to reconnect the natural landscape to support the safe passage of animals. The following pages will identify the negative impacts and legacy of road infrastructure in fragmenting natural landscapes and examine the policies that can address these impacts across the region.

The research for this MRP was supported by funding through a Partnership Development Grant of the Social Sciences and Humanities Research Council of Canada (SSHRC), held by Prof. Nina-Marie Lister through the Ecological Design Lab at Ryerson University. The project, Safe Passage: Towards and Integrated Planning Approach for Landscape Connectivity has a goal to: develop an integrated approach to the planning and implementation of wildlife crossing structures to improve landscape connectivity in Canada. This MRP is designed to help work towards this goal.

\subsection{Research question and objectives}

Research question:

To what extent are the policies that guide the planning and design of roads, and the protection/recovery of biodiversity integrating Ontario's biodiversity commitments that support landscape connectivity (and wildlife crossing structures) into southern Ontario and GGH road projects?

\section{Research objectives:}

1) To identify key Ontario policies that intersect both road projects and biodiversity recovery;

2) to establish evaluation criteria that link the Ontario Biodiversity Strategy commitments to conservation approaches that focus on landscape connectivity and promoting wildlife crossing structures;

3) to evaluate effectiveness of selected policies in meeting established biodiversity commitments and promoting landscape connectivity in road projects; and

4) to provide context for future discussions around how to improve Ontario's policy framework to better integrate biodiversity values into the planning and design of Ontario's roads as the $\mathrm{GGH}$ continues to rapidly urbanize. 


\subsection{Setting the context: literature review and policy overview}

This section outlines the trend of biodiversity decline and frames how interventions in the planning and design of Ontario roadways could help to improve conditions for wildlife. This will consist of a summary of relevant literature that outlines the connection between biodiversity loss and landscape fragmentation, emerging action in policy and conservation responses, and outline the current state of policy in Ontario related to road projects and reconnecting landscapes.

\subsection{Biodiversity decline and conservation responses}

\subsubsection{Biodiversity trends}

The direct impacts of human development are leading to the worldwide loss of biodiversity and wildlife (Johnson et al., 2017; WWF, 2014; McGill et al., 2015; Steffen et al., 2011). The extent of human impact and the scale of biodiversity decline has led some ecologists to identify the time since the Industrial Revolution as a new geologic period, dubbed the "Anthropocene" (Steffen et al., 2011). The Anthropocene epoch is identified by the presence and widespread impact of human activities, leading to modifications of more than $50 \%$ of the Earth's terrestrial cover, major changes in atmospheric composition (namely $\mathrm{CO} 2$ and other greenhouse gasses), and widespread impacts to ocean chemistry (McGill et al., 2015; Crutzen, 2002).

The pace of human development and widespread geographic extent of our impacts have initiated a major extinction event and biodiversity crisis (Johnson et al., 2017; WWF, 2014; McGill et al., 2015). The International Union for Conservation of Nature (IUCN) Red List of threatened and endangered species has identified that $25 \%$ of mammal species, $12.5 \%$ of bird species and over $40 \%$ of amphibian species are identified as threatened world-wide (McGill et al., 2015). The World Wildlife Fund in their 2014 Living Planet Index identified that within the 30 years between 1970 and 2010 that all vertebrate species declined by 52\% (WWF, 2014). This was based on an analysis of trends for more than 10,380 populations of 3,338 mammal, bird, reptile, amphibian and fish species (Figure 3) (WWF, 2014).

Figure 3: WWF's Global Living Planet Index: Vertebrate Species Abundance 1970 - 2010 (WWF, 2014)

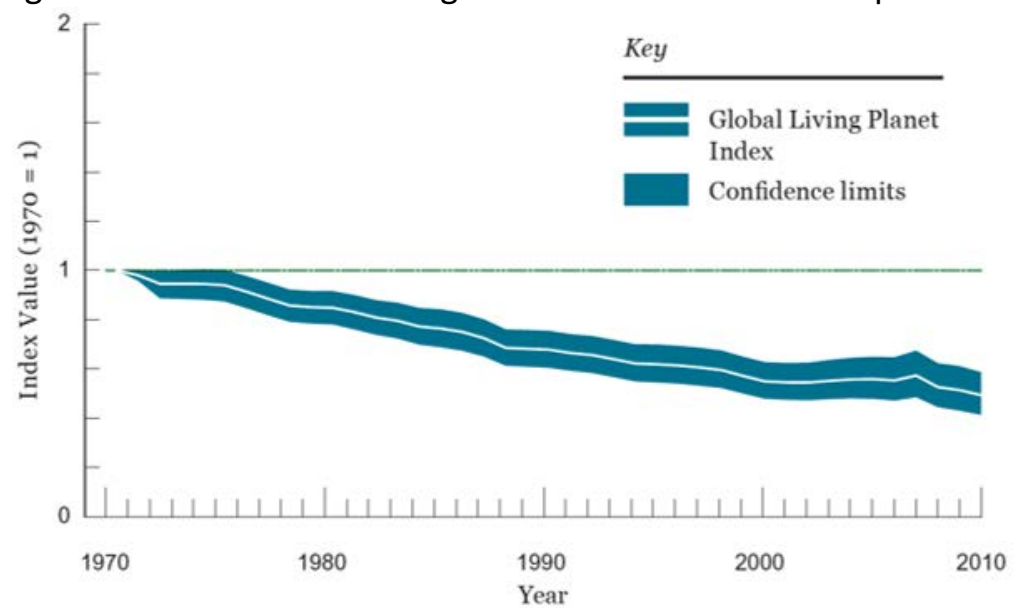

In Ontario and across the GGH the trend of biodiversity decline is having a direct impact on native species. Habitat loss and fragmentation represents an imminent threat to biodiversity that is most intense in urbanizing areas (Cowie, 2011; Lister et al., 2015). This is especially the case across southern and eastern Ontario where productive farmland and a temperate climate have led to the highest levels of population density across the county (Environment Canada, 2014). Across the southern Ontario, more 
than $67 \%$ of the landscape has been converted to human-uses (OBC, 2015). This represents a major threat to biodiversity as significant habitat loss and fragmentation has converted an area that historically was dominated by forests and wetlands into largely agricultural and urban uses (OBC, 2015).

Since European colonization and settlement in southern Ontario, the region has lost approximately $80 \%$ of woodlands, $72 \%$ of wetlands (Figure 4) and 99\% of grasslands (ECO, 2011; DUC, 2010). This dramatic loss of natural habitat has led to more than 231 native species listed as 'at-risk' under the Province's Endangered Species Act, 2007, most of which are found in southern Ontario (Figure 5) (ECO, 2016; MNRF, 2018). Within the population-rich and heavy urbanized region of the Greenbelt and GGH, approximately $97 \%$ of at-risk species are further threatened by habitat loss and fragmentation, which are both identified as primary drivers of their decline (Cowie, 2011). As early as the mid 1980s habitat fragmentation has been identified as "the most serious threat to biological diversity" (Wilcox \& Murphy, 1985). In settled landscapes reconnecting the natural landscape must be a necessary element within any action to promote biodiversity conservation and recovery.

Figure 4: Wetland cover in southern Ontario 1800 - 2002 (DUC, 2010)
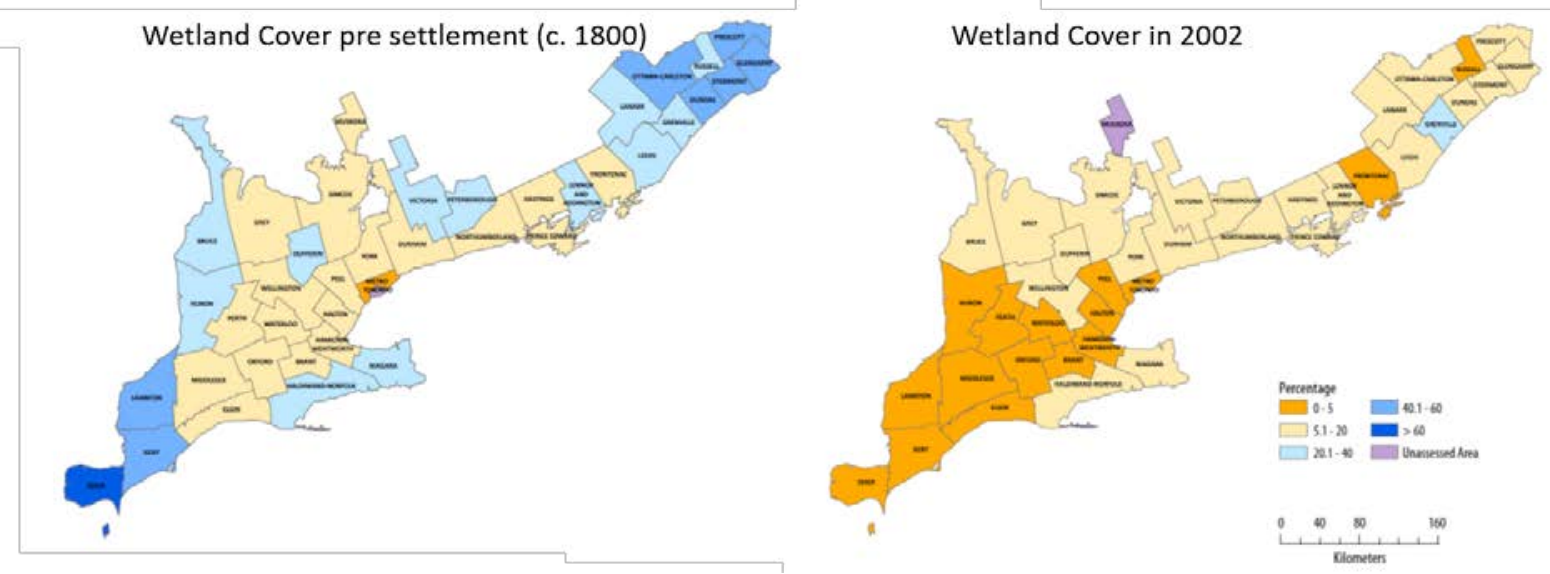
Figure 5: Concentration of Species at Risk richness across Ontario (OREG, 2010)

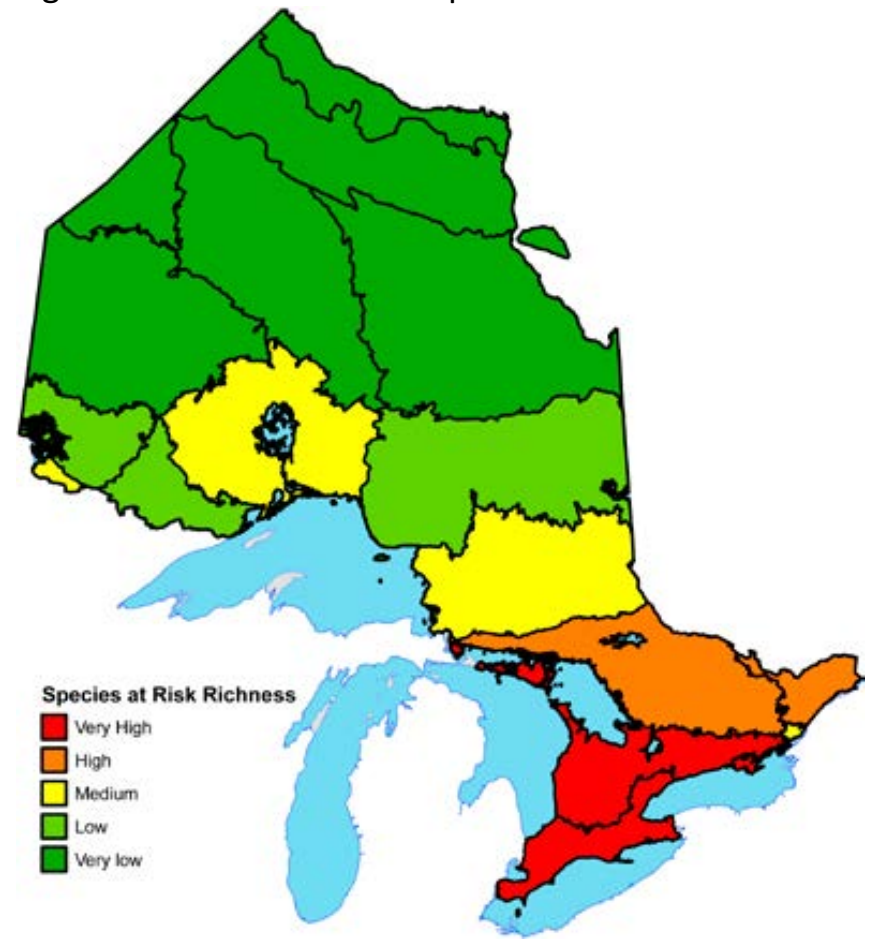

\subsubsection{Landscape connectivity}

Landscape connectivity is acknowledged as a core tenant of contemporary conservation strategies (Beckmann \& Hilty, 2014; Coristine et al., 2018; MNR, 2010). Planning for connectivity ensures that natural features, functions and linkages are all considered as component parts of a heathy and livable landscape (MNR, 2010). Historically, approaches to conserving wildlife focused on protecting individual natural features and did not adequately recognize the importance of a well-connected landscape for the benefit of biodiversity (ECO, 2011).

Over the last three decades a greater recognition of the importance of maintaining, improving or recreating natural connections between core habitat has emerged as a response to biodiversity decline. This approach aims to restore connectivity to a settled landscape by adding natural corridors that begin to replicate the interconnected nature of the landscape prior to development (Noss, 1987). A connected natural landscape can help to improve biodiversity health by providing important ecosystem servicesincluding flood control, nutrient cycling and climate change mitigation - that are required for healthy animal and human communities (Costanza et al., 1997; MNR, 2010). Across human-dominated regions, connectivity supports multi habitat organisms who regularly move across the landscape to obtain their daily and lifetime needs; enables genetic flow amongst individual populations of wildlife; and increases resiliency and ecosystem function (Beckmann \& Hilty, 2014; Forman, et al., 2003; Coristine et al., 2018).

The emergence of the sub discipline of Landscape Ecology in the 1980s shifted ecological focus to a broader scale to better understand species movement and natural processes across a natural region (Turner, 2005). By the 1990s and 2000s conservation attention was focused to the direct and indirect impacts caused by roads to ecosystem health as the sub discipline of Road Ecology emerged (Beckmann 
and Hilty, 2014). A greater understanding of both Landscape Ecology and Road Ecology have begun to lead to changes in land use planning across North America. The emergence of natural heritage systems planning and complimentary approaches that aim to prioritize landscape connectivity have been recognized as effective means of recovering biodiversity in urban regions (Turner, 2005; ECO, 2011).

Landscape connectivity does not come without potential negative consequences for biodiversity. Scientists including Simberloff \& Cox were early to point out that in the absence of local research, creating natural corridors could lead to unintended consequences including: increased exposure to natural areas from unwanted predators, fires and humans, as well as increased risk of disease and invasive species spread (Simberloff \& Cox, 1987; Deshaies, 2017). This concern was countered by Reed Noss and others who acknowledged the need for additional localized research, but that any reasonable conservation strategy must address habitat fragmentation and aim to reconnect the natural landscape (Noss, 1987). Strategic and widespread landscape connectivity based on understanding of local conditions will help to improve the conditions for biodiversity and reduce unwanted side effects of connectivity.

Table 1: Major disciplines and terms related to landscape connectivity

\begin{tabular}{|l|l|}
\hline Landscape ecology & $\begin{array}{l}\text { The study of how landscape structures affect the } \\
\text { processes that determine the abundance and } \\
\text { distribution of species and organism (Turner, } \\
\text { 1989; Taylor et al., 1993; MTO, 2017a) }\end{array}$ \\
\hline Landscape/wildlife connectivity & $\begin{array}{l}\text { The degree to which the landscape facilitates or } \\
\text { impedes animal movement and other ecological } \\
\text { flows. (Forman et al., 2003; Hack, 2018; } \\
\text { Beckmann and Hilty, 2014; Taylor et al., 1993) }\end{array}$ \\
\hline Natural heritage systems planning & $\begin{array}{l}\text { Born out of landscape connectivity thinking, } \\
\text { natural heritage systems planning is a strategic } \\
\text { approach to addressing biodiversity loss, land use } \\
\text { change and the uncertainties of climate change. } \\
\text { This approach is premised on identifying and } \\
\text { protecting spatially and functionally } \\
\text { interconnected natural systems (MNR, 2010; } \\
\text { Wise et al. 2014) }\end{array}$ \\
\hline Countryside Conservation & $\begin{array}{l}\text { European model of landscape management that } \\
\text { aims to plan for the amenity objectives of } \\
\text { maintaining wildlife historic features and scenic } \\
\text { beauty of landscapes. A key element of this } \\
\text { practice is to take a broad-scale landscape } \\
\text { approach to planning (Green, 1996; MNR, 2010). }\end{array}$ \\
\hline Road ecology & $\begin{array}{l}\text { The study of the unintended ecological } \\
\text { implications of roads. Road Ecology seeks to } \\
\text { contribute knowledge around how to avoid, } \\
\text { minimize, and compensate for roads' negative } \\
\text { impacts on individual species, populations, } \\
\text { communities, and ecosystems (Van der Ree et al. } \\
\text { 2011). }\end{array}$ \\
\hline
\end{tabular}


The degree to which a natural system is able to withstand, adsorb and adjust to disturbances (i.e. climate change, flooding, major weather events, and human-disturbance) while maintaining function and structural integrity. Occasionally changes may result in a reorganization of a natural system's structures and functions into a new, or alternate steady state.

(Brocki et al., 2014; Holling, 1973; Lister, 2014)

\subsubsection{Roads and fragmentation}

The expansion and proliferation of road networks have acted as a marker of economic progress and accessibility for much of the last two centuries (Forman et al., 2003). Roads have been identified as an inevitable part of growth and development (Beckman and Hilty, 2014). Expanding road networks have been instrumental in ensuring economic and social sustainability for cities and urban regions, connecting people to resources (Hack, 2018; Beckman and Hilty, 2014).

Through the $19^{\text {th }}$ and $20^{\text {th }}$ Centuries the planning and design of North America's road network was primarily focused on ease of terrain, soil, and did not consider the needs of wildlife or species movement (Beckmann and Hilty, 2014; Beckmann et al., 2014). To better align the expansion of the region's road network with landscape connectivity, an interdisciplinary solution must be found that addresses the complex interactions between roads and habitat fragmentation.

The impact to biodiversity caused by roads can be both nuanced and profound, direct and indirect (Table 2 \& Figure 6) (ECO, 2008; Hack, 2018). Over the last 50 years, continuous road building in North America has caused impacts to wildlife that range from the most visible: including collisions with vehicles causing wildlife mortality; to less easily recognizable: including a reduction in gene flow between species populations (ECO, 2008; Jaeger et al., 2005; Keller \& Largiader, 2003; OREG, 2010; Lister et al., 2015). 
Table 2: Major ecological effects of roads to wildlife

\begin{tabular}{|c|c|c|c|c|c|c|c|c|}
\hline \multirow[t]{2}{*}{ Impact } & \multirow[t]{2}{*}{ Explanation } & \multirow[t]{2}{*}{ Source(s) } & \multicolumn{2}{|c|}{ Nature of impact } & \multicolumn{2}{|l|}{ Time scale } & \multicolumn{2}{|c|}{$\begin{array}{l}\text { Spatial Scale } \\
\text { (Geographic) }\end{array}$} \\
\hline & & & $\begin{array}{l}\text { Direct } \\
\text { (mortality) }\end{array}$ & $\begin{array}{l}\text { Indirect } \\
\text { (behavioural) }\end{array}$ & $\begin{array}{l}\text { Immediate } \\
\text { (short term) }\end{array}$ & $\begin{array}{l}\text { Cumulative } \\
\text { (longer term) }\end{array}$ & Local & $\begin{array}{l}\text { Regional } \\
\text { or larger }\end{array}$ \\
\hline Road mortality & $\begin{array}{l}\text { Direct impact on roads } \\
\text { leading to species death } \\
\text { (wildlife - vehicle } \\
\text { collisions) }\end{array}$ & $\begin{array}{l}\text { Beckmann and Hilty, } \\
\text { 2014; Benítez-López } \\
\text { et al. 2010; Fahrig \& } \\
\text { Rytwinski } 2009\end{array}$ & $x$ & & $x$ & & $x$ & \\
\hline $\begin{array}{l}\text { Genetic isolation of } \\
\text { subpopulations }\end{array}$ & $\begin{array}{l}\text { Barriers to movement } \\
\text { across landscapes to } \\
\text { find new mates leads to } \\
\text { higher rates in } \\
\text { inbreeding }\end{array}$ & $\begin{array}{l}\text { Forman \& Alexander } \\
\text { 1998; Hack, } 2018\end{array}$ & $x$ & & & $x$ & & \\
\hline $\begin{array}{l}\text { Reduced species } \\
\text { resilience to } \\
\text { climatic shifts }\end{array}$ & $\begin{array}{l}\text { Barriers to shifting } \\
\text { northward as climatic } \\
\text { ranges change }\end{array}$ & $\begin{array}{l}\text { Lister et al, 2015; } \\
\text { Hack, } 2018\end{array}$ & $x$ & & & $x$ & $x$ & $x$ \\
\hline $\begin{array}{l}\text { Limiting access to } \\
\text { resources }\end{array}$ & $\begin{array}{l}\text { isolated habitats may } \\
\text { lead to over use of } \\
\text { limited resources }\end{array}$ & $\begin{array}{l}\text { Beckmann and Hilty, } \\
2014\end{array}$ & $x$ & $x$ & & $x$ & $x$ & $x$ \\
\hline $\begin{array}{l}\text { Introduction of } \\
\text { invasive species }\end{array}$ & $\begin{array}{l}\text { through new pathways } \\
\text { into previously interior } \\
\text { habitat }\end{array}$ & ECO, 2008 & & $\mathrm{x}$ & $\mathrm{x}$ & $x$ & $x$ & $x$ \\
\hline $\begin{array}{l}\text { Increased human } \\
\text { access }\end{array}$ & $\begin{array}{l}\text { decreased habitat } \\
\text { quality through human } \\
\text { access }\end{array}$ & $\begin{array}{l}\text { ECO, 2008; } \\
\text { Beckmann and Hilty, } \\
2014\end{array}$ & $x$ & $x$ & $x$ & $x$ & $x$ & $x$ \\
\hline
\end{tabular}


Figure 6: Three major interactions of mobile wildlife with roads (Hack, 2018)

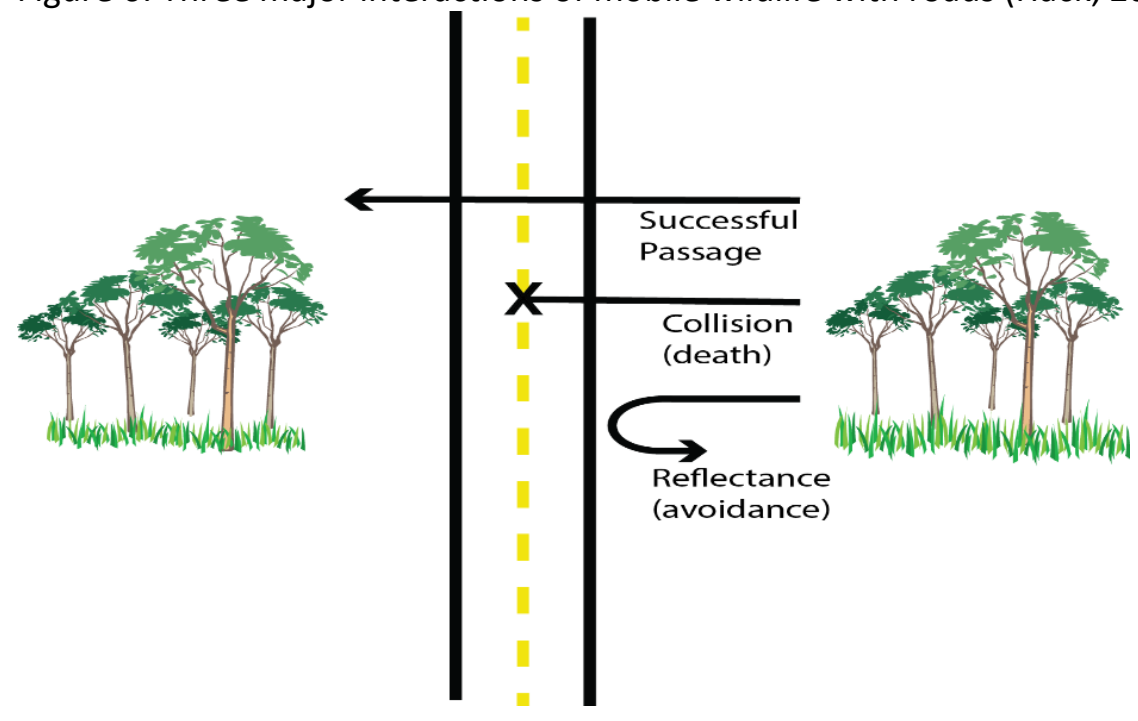

In urban areas as the density of roads increases natural habitat becomes increasingly fragmented into smaller and smaller patches (MTO, 2017a). Smaller habit patches lead multi-habitat animals to cross roads as they move across the landscape, leading to higher rates of collisions and road avoidance (ECO, 2008; OREG, 2010).

In the 2015 State of Ontario's Biodiversity Report (SOBR), analysis identified the proliferation of roads in Ontario has increased by $69 \%$ between 1935 and 2005, from 24,200 km to more than 40,800 km (Figure 7) (OBC, 2015). The clear majority of this network is found in areas south and east of the Canadian Shield (Figure 2) (OBC, 2015). Additional analysis in the SOBR report demonstrated the intensity of fragmentation across southern Ontario, with estimates indicating the average roadless patch of landscape at less than $1.3 \mathrm{~km}^{2}$, down to only $0.03 \mathrm{~km}^{2}$ in the Toronto area (Figure 8) (OBC, 2015).

Figure 7: Road length in Ontario $1935-2005$ (OBC, 2015)

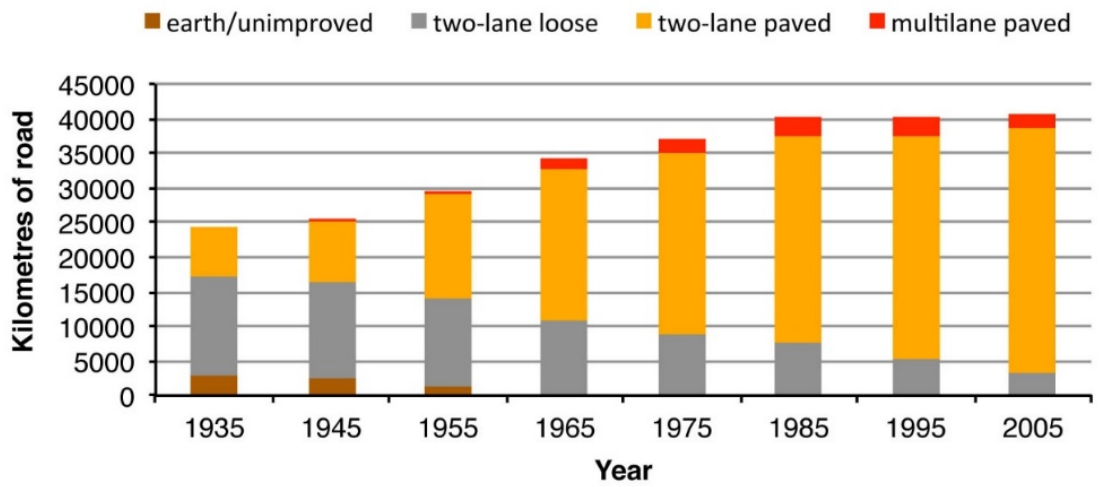


Figure 8: Effective Mesh Size in southern Ontario, 2011 (OBC, 2015)

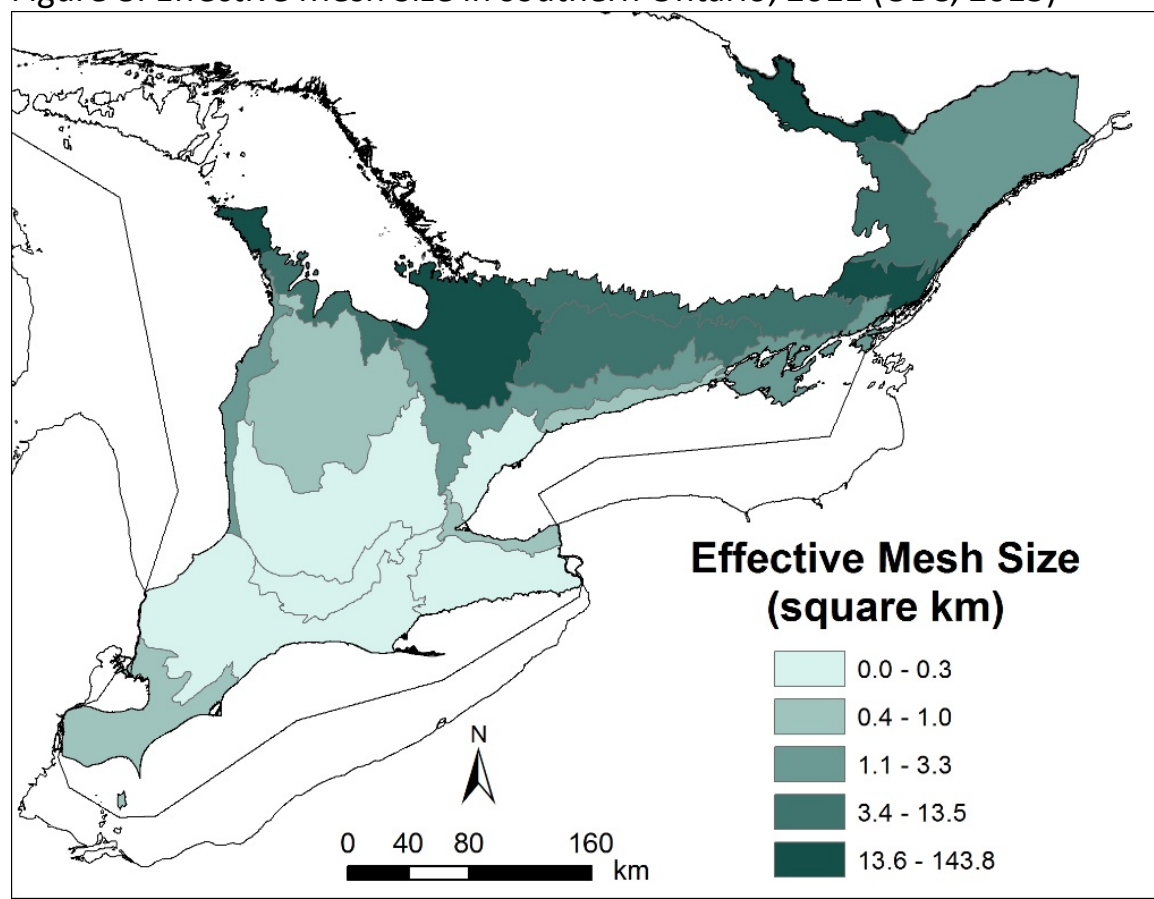

\subsubsection{Improving connectivity: wildlife crossing structures}

Minimizing the impacts of road project to biodiversity is best achieved through avoiding key habitats and areas that link habitat patches in the planning and design processes. However, if roads are sited in areas with potential conflicts between vehicles and nature, negative impacts can be avoided through construction of linkages across roads for wildlife (Figure 8). Wildlife crossing structures increase compatibility of wildlife movement with roads and are an important element of infrastructure to overcome habitat fragmentation (Lister et al., 2015; Crooks \& Sanjayan, 2006; Beckman et al., 2010). Road overpasses and underpasses can be created to mimic natural corridors to restore and improve connectivity impacted by roads (Hadad, 2015). 
Figure 9: Images of examples of wildlife crossing structures in Ontario (top-left to bottom-right): box culvert underpass (CK. Gunson), 30m overpass on Hwy. 69 (@K. Gunson), open-grate tunnel (@A. Mui), concrete exclusion wall and culvert (CK. Gunson) (source: OREG, 2010)
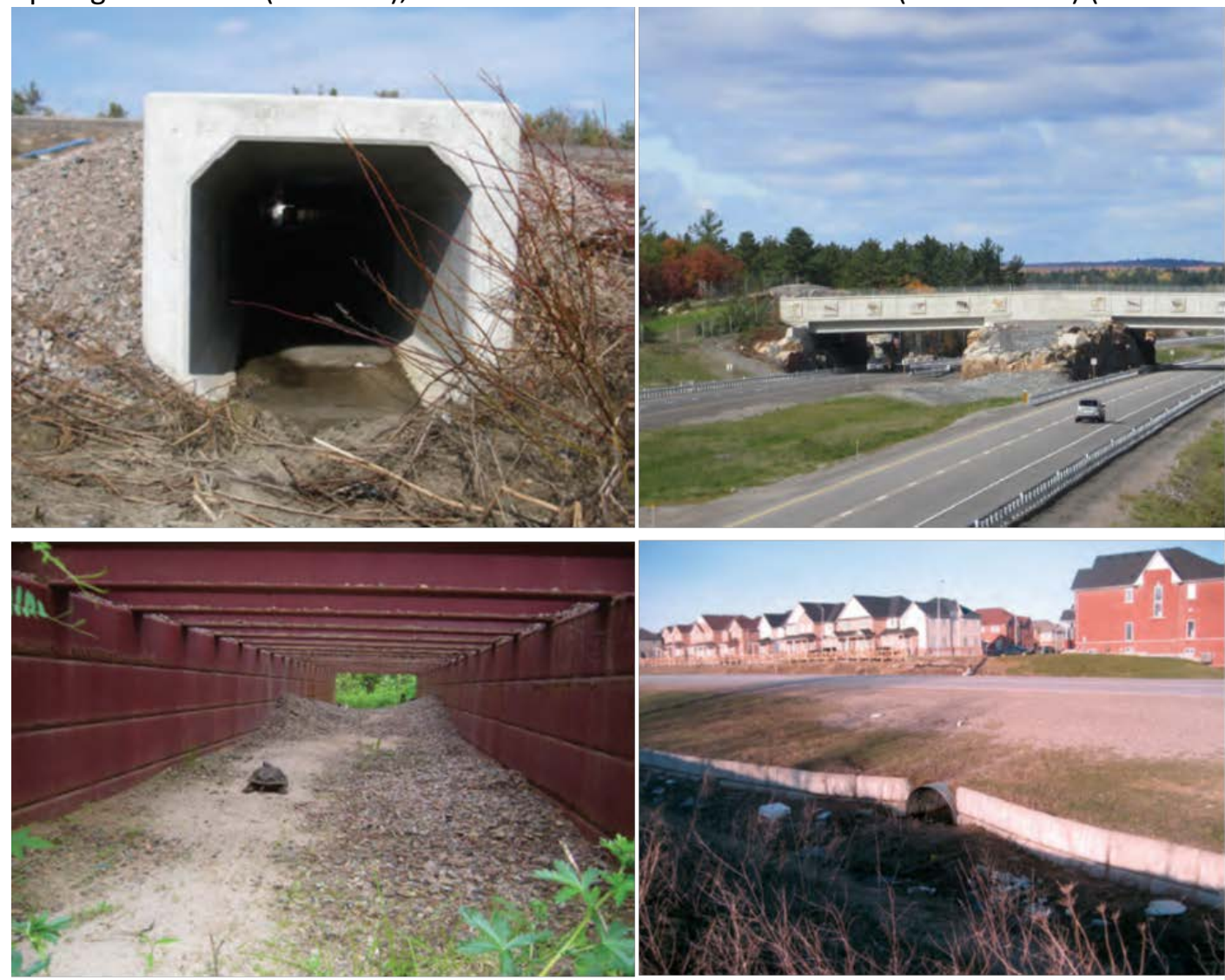

The integration of wildlife crossing structures, or ecopassages, are widely recognized as an important intervention to reconnecting fragmented habitat and mitigating the impacts of roads (Lister et al., 2015; OREG, 2010; ECO, 2015). Wildlife crossing structures are proven to reduce wildlife-vehicle collisions by an average of $87 \%$ for large animals, enabling their safe passage (Kociolek et al., 2015).

Together with appropriate fencing, the introduction of wildlife crossing structures can direct targeted species towards safe passages either above or below roads (OREG, 2010). Overpasses help to connect landscapes, typically for mammals, by facilitating movement over a road through the use of structures that act as land bridges, sometimes solely dedicated for wildlife movement or combined with other passive recreation uses (OREG, 2010; USDOT, 2011). Underpasses help to facilitate movement for reptiles, amphibians, mammals and other species beneath a road. These structures can range from the creations of smaller elements like pipes, tunnels, culverts to larger structures like bridges, viaducts, and box culverts (OREG, 2010; USDOT, 2011).

The cost associated with the creation of wildlife crossing structures creates an additional expense to road projects. New innovations in the design of wildlife crossing structures are actively being explored to reduce barriers and better integrate the use of ecopassages as part of the norm for road projects (ARC, n.d.). Organizations including ARC Solutions have been created specifically to explore the cost and design barriers to help increase the uptake of this successful biodiversity solution (ARC, 2018). ARC 
Solutions is an international network of NGOs, transportation agencies, and academics promoting and innovating new opportunities for widespread implementation. In October of 2014, ARC Solutions facilitated a workshop with a focus on the planning, design, and construction of wildlife crossing structures (ARC n.d.). Through this workshop, it was found that the costs of wildlife crossing structures could be greatly reduced by assessing opportunities for use of new materials, technologies and products such as modular construction (ARC, n.d.). Innovation around the creation of standards for wildlife crossing structures offers a significant opportunity to popularize this biodiversity solution, known to have positive impacts in reconnecting landscapes.

\subsection{Biodiversity commitments and connecting landscapes}

Biodiversity loss (as outlined in section 2.1) is a worldwide phenomenon and requires widespread intervention across many sectors to address this crisis. A comprehensive and interdisciplinary approach to road planning is needed to adequately address biodiversity needs and ecosystem functioning in heavily developed areas like southern Ontario and the GGH (Lister et al., 2015). The negative impacts of roads to wildlife, while a complex problem can be reduced through proper siting, design and management of roads (Hadad, 2015). Reconnecting fragmented landscapes will be an important element in ongoing efforts to recover biodiversity and improve landscape resilience in an era of climate change.

International, National, and Provincial targets highlighted below all contain important elements that outline the need to improve landscape connectivity, while increasing protection for other elements of natural heritage. The planning and design of roads across the landscape will be an important consideration to improve ecological resilience and manage for the safe passage of animals as associated action is taken to meet biodiversity commitments.

\subsubsection{International and national biodiversity targets}

Biodiversity recovery has been a focus of the international community for more than three decades, with the first major international discussions occurring at the Earth Summit in 1992 (UN CBD, 2000). By 1993 the United Nation's Convention on Biological Diversity (UN CBD) was ratified and went in to force as an international treaty in Canada (ECCC, 2017). The UN CBD outlines the problem of biodiversity loss and identifies goals and obligations around conservation and sustainable development for ratifying countries to act on (UN CBD, 2000). The Convention was most recently updated in 2010 in Nagoya, Japan as the national parties adopted the Strategic Plan for Biodiversity 2011 - 2020 (UN CBD, 2010). This Strategic Plan outlined the following vision and mission:

Vision: "By 2050, biodiversity is valued, conserved, restored and wisely used, maintaining ecosystem services, sustaining a healthy planet and delivering benefits essential for all people".

Mission: "take effective and urgent action to halt the loss of biodiversity in order to ensure that by 2020 ecosystems are resilient and continue to provide essential services, thereby securing the planet's variety of life, and contributing to human well-being, and poverty eradication" (Secretariat of CBD, 2010) 
These high-level statements were underscored by an obligation for all party nations to develop and update national biodiversity strategies that integrate a set of 20 targets developed by the UN CBD (UN $C B D, 2010)$. These 20 targets, dubbed the Aichi Targets after the region of Japan where the Plan was developed, are intended to be implemented into appropriate policy in party nations (UN CBD, 2010). Of the 20 targets, four have particular relevance to the importance of reconnecting fragmented landscapes and would require intervention in the process of road projects (Table 3 ).

Table 3: Aichi targets and implication for landscape connectivity and road projects

\begin{tabular}{|c|c|}
\hline Aichi Targets & Implication for landscape connectivity \\
\hline $\begin{array}{l}\text { Aichi Target \#1 } \\
\text { By } 2020, \text { at the latest, people are aware of } \\
\text { the values of biodiversity and the steps } \\
\text { they can take to conserve and use it } \\
\text { sustainably }\end{array}$ & $\begin{array}{l}\text { This target seeks to broadly integrate biodiversity } \\
\text { values into relevant policy, and to popularize the } \\
\text { importance of biodiversity with the public. This } \\
\text { could include the widespread implementation of } \\
\text { interventions, such as wildlife crossing structures } \\
\text { to better improve landscape connectivity around } \\
\text { roads. }\end{array}$ \\
\hline $\begin{array}{l}\text { Aichi Target \#2 } \\
\text { By } 2020 \text {, at the latest, biodiversity values } \\
\text { have been integrated into national and } \\
\text { local development and poverty reduction } \\
\text { strategies and planning processes and are } \\
\text { being incorporated into national } \\
\text { accounting, as appropriate, and reporting } \\
\text { systems }\end{array}$ & $\begin{array}{l}\text { This target identifies the importance of } \\
\text { integrating biodiversity values into (amongst } \\
\text { other areas) relevant planning processes. This } \\
\text { speaks to the significance the planning process } \\
\text { can have in helping achieve biodiversity recovery. }\end{array}$ \\
\hline $\begin{array}{l}\text { Aichi Target \#5 } \\
\text { By } 2020 \text {, the rate of loss of all natural } \\
\text { habitats, including forests, is at least } \\
\text { halved and where feasible brought to zero, } \\
\text { and degradation and fragmentation is } \\
\text { significantly reduced }\end{array}$ & $\begin{array}{l}\text { This target specifically identifies the need to } \\
\text { significantly reduce habitat fragmentation. The } \\
\text { planning and design of roads, associated with } \\
\text { expanding human development, has an } \\
\text { enormous impact on the degradation and } \\
\text { fragmentation of natural habitats. }\end{array}$ \\
\hline $\begin{array}{l}\text { Aichi Target } \# 11 \\
\text { By } 2020 \text {, at least } 17 \% \text { of terrestrial and } \\
\text { inland water, and } 10 \% \text { of coastal and } \\
\text { marine areas, especially areas of particular } \\
\text { importance for biodiversity and ecosystem } \\
\text { services, are conserved through effectively } \\
\text { and equitably managed ecologically } \\
\text { representative and well-connected } \\
\text { systems of protected areas and other } \\
\text { effective area-based conservation } \\
\text { measures, and integrated into the wider } \\
\text { landscape and seascapes. }\end{array}$ & $\begin{array}{l}\text { This target identifies that the creation of } \\
\text { protected areas is a key component to } \\
\text { biodiversity recovery and the maintenance of } \\
\text { ecosystem services. This target also recognizes } \\
\text { the importance of maintaining and improving } \\
\text { landscape connectivity and "well-connected } \\
\text { systems" of protected habitat. This should have } \\
\text { implications for the planning, design and } \\
\text { maintenance of roads within and between } \\
\text { protected areas. }\end{array}$ \\
\hline
\end{tabular}

Nationally, the Canadian Biodiversity Strategy was first developed in 1995 to outline the county's commitments under the UN CBD (ECCC, 2017). These commitments were updated in 2016 to create the 
2020 Biodiversity Goals and Targets for Canada (targets relevant to landscape connectivity identified in Table 4) (ECCC, 2016).

Table 4: Relevant 2020 Biodiversity Targets for Canada

\begin{tabular}{l}
2020 Biodiversity Targets for Canada relevant to landscape connectivity and road projects \\
Canada's Target \#1 \\
By 2020, at least 17 percent of terrestrial areas and inland water, and 10 percent of coastal and \\
marine areas, are conserved through networks of protected areas and other effective area-based \\
conservation measures. \\
\hline Canada's Target \#4 \\
By 2020, biodiversity considerations are integrated into municipal planning and activities of major \\
municipalities across Canada
\end{tabular}

\subsubsection{Ontario's biodiversity targets}

In Canada due to our system of government much of the responsibility to manage and regulate our biodiversity falls to provincial and territorial governments (ECO, 2012). The role of the Government of Ontario with respect to biodiversity conservation involves both: implementing policies and legislation that guides the protection, stewardship and use of natural resources; and offering direction on land use planning and transportation systems (MNR, 2012). Due to the central role of the government of Ontario, the lens of this MRP will be focused on provincial policies that guide provincial and municipal road projects, and protect biodiversity.

The Ontario Biodiversity Council - a group of conservation and environmental groups, industry associations, Indigenous organizations, academics and government agencies - has led to the development of Ontario's Biodiversity Strategy in 2011 (OBC, 2011). This Strategy was developed to customize the Aichi and Canadian targets to local conditions and outline a path forward for the province (Figure 10). This work informed the implementation plan Biodiversity It's in Our Nature developed by the Ministry of Natural Resources and Forestry to inform government-wide action on biodiversity (MNRF, 2012). This document includes over 100 actions and activities to be implemented to achieve the Biodiversity commitments and "secure our prosperity and quality of life" (MNR, 2012).

Ontario's Biodiversity Strategy lays out a vision for biodiversity recovery and a set of 15 targets, each with associated actions in order to meet these targets and achieve the vision.

Vision: "a future where biodiversity loss is halted and recovery is advanced. People value, protect and enhance biodiversity and the ecosystem services essential for human health and well-being"

Amongst the Ontario Biodiversity Strategy's identified targets are four that are particularly relevant to the issues identified in this paper around habitat fragmentation and implementing wildlife crossing structures to reconnect landscapes across roads, outlined in Table 5. 
Figure 10: International, national and provincial targets relevant to landscape connectivity and road projects

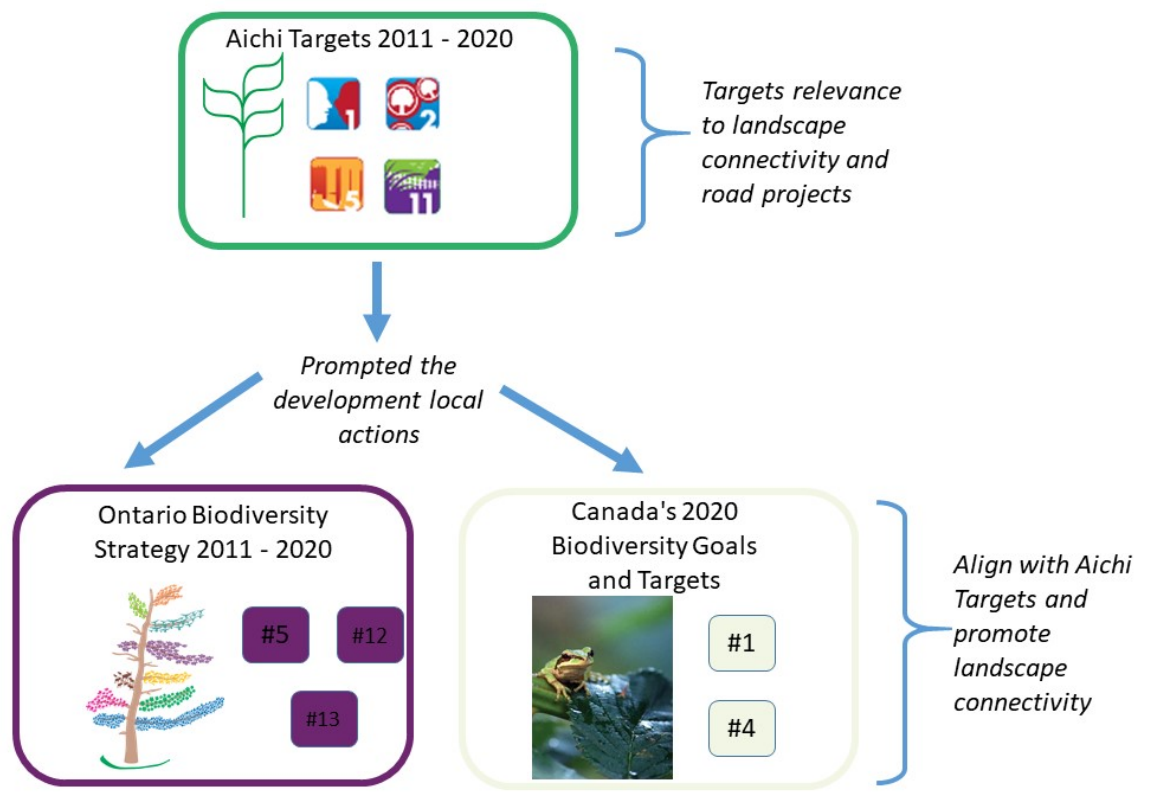

Table 5: Relevant Ontario Biodiversity Strategy Targets

\section{Ontario Biodiversity Strategy Targets relevant to landscape connectivity and road projects}

Ontario's Target \#5

By 2020, all relevant policies and programs integrate biodiversity values

\section{Ontario's Target \# 12}

By 2015, natural heritage systems plans and biodiversity conservation strategies are developed and implemented at the municipal and landscape levels

Ontario's Target \#13

By 2020 , at least $17 \%$ of terrestrial and aquatic systems are conserved through well-connected networks of protected areas and other effective area-based conservation measures

Ontario's Target \#13, closely mirrors Canada's Target \#1 and Aichi Target \#11, and has received increased attention in recent years as the Federal government has established a National Advisory Panel to advice the federal government on strategies to achieve this target (NAP, 2018). These aligned targets seek to increase the proportion of terrestrial land protected for nature to $17 \%$ of the total land base, with specific provisions for landscape connectivity. These targets are based on IUCN's definition of a protected area: a geographically defined area that is "recognized, dedicated and managed... to achieve the long-term conservation of nature..." (CPAWS, 2017). These targets also include the opportunity to add areas deemed "other effective area-based conservation measures", which has a slightly different definition, as areas that are managed in ways that achieve "sustained long-term outcomes for the in-situ conservation of biodiversity..." (SBSTTA, 2018).

The need to simultaneously take action to protect biodiversity and improve landscape connectivity is outlined, either directly or indirectly in the highlighted targets. The role of the planning and design of roads remains an important element in any action to meet these biodiversity targets. 


\subsection{Polices at the intersection of road projects and biodiversity recovery in Ontario}

The Provincial government holds the primary responsibility to implement biodiversity targets, managing natural resources, and preserving ecosystem services (ECO, 2011). The Province's role with respect to biodiversity is to implement polices and legislation that guides the protection, stewardship, and use of natural resources (MNR, 2012).

In Ontario more than 60 separate federal and provincial statutes, regulations, and government policies are potentially relevant to the environmental aspects of provincial transportation projects and activities (MTO, 2014). For municipal road projects, additional legislation and polices become applicable including requirements of municipal Official Plans, zoning by-laws and Environmental Impact Study (EIS) requirements.

Environmental compliance and guidance for road projects is primarily given through land use policies (e.g. Provincial Policy Statement and Official Plans) and regulatory policies (e.g. Environmental Assessment and Endangered Species Act) (MTO, 2014).

\subsubsection{Land use planning}

In Ontario the Planning Act sets the legal framework for how municipalities are to plan and accommodate growth within their communities (MMAH, 2014). This Act, which is largely implemented through the Provincial Policy Statement (PPS), enables the Province of Ontario to develop policies that reflect provincial interests, which municipalities are required to address in planning decisions (MMAH, 2014). The PPS represents the minimum standards that municipalities across the province must be consistent with as they update Official Plans (OPs) or make planning decisions. In addition to the PPS, regional plans including the Growth Plan for the Greater Golden Horseshoe (Growth Plan), Greenbelt Plan, Oak Ridges Moraine (ORM) Conservation Plan and Niagara Escarpment (NE) Plan have been developed to provide guidance and attention to provincial priorities in areas where development pressure are most intense (Figure 11). 
Figure 11: Provincial land use plans in the Greater Golden Horseshoe (MMA, 2017a; MMA, 2017b)
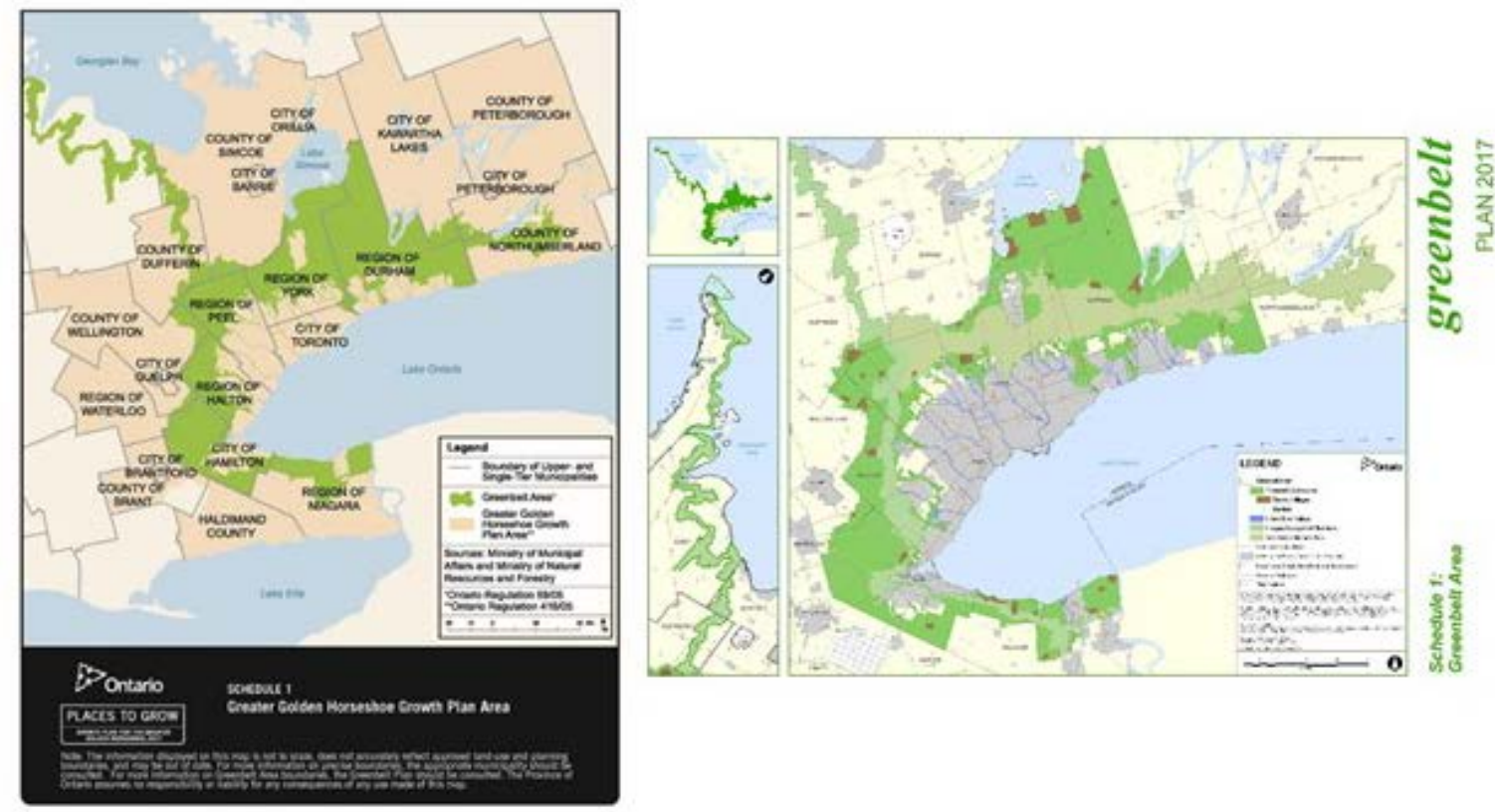

Recent action to integrate biodiversity considerations into land use plans across southern Ontario and the GGH has been underway. The PPS now includes policies that will ensure municipalities identify Natural Heritage Systems in their Official Plans; and the updated Growth Plan includes policies to protect a regional Natural Heritage System (MMA, 2014; MMA, 2017a).

There remains a disconnect between the systems-level protection for natural heritage, and road and infrastructure polices which do not mention biodiversity or connectivity (MMAH, 2014). The Environmental Commissioner of Ontario (ECO) notes that despite the PPS's new language around natural heritage protection, the policy is overall "wholly inadequate to safeguard natural heritage against the irreparable damage and loss of biodiversity that inevitably accompany development" (ECO, 2015).

\subsubsection{Regulatory policy}

For road projects, a range of regulatory policies must be adhered to in order to gain necessary legislative approvals to proceed. These range from policies the guide drainage design, to noise mitigation, to excess soil management (MTO, 2014). The primary regulatory policies and processes that guide the planning and design of road project as they relate to biodiversity concerns are the Environmental Assessment (EA) process, and Endangered Species Act (ESA) regulations (Crowley, personal communication, June 14 2018; Gunson, personal communication, May 3 2018; Karch, personal communication, May 4 2018; Carruthers, personal communication, May 4 2018; Charlton, AndrewMcBride \& Hazell, personal communication, May 24 2018; Dagg-Foster, personal communication, June 6 2018; Levick, personal communication, June 20 2018; Nix \& Lefler, 2018; Scott, personal communication, July 5 2018).

The planning and preliminary design of municipal and provincial road projects are subject to either an individual EA or a streamlined (Class) EA (MECP, 2018; MTO, 2000). The EA process allows proponents to 
assess potential environmental effects and benefits of a project (MTO, 2014). A streamlined or Class EA establishes a planning and approval process for applicable projects which a proponent commits to following in order to gain efficiencies and cost savings in the delivery of pre-approved and predictable EA processes (MTO, 2000). Typically for the delivery of municipal and provincial roads the: Class EA for Municipal Infrastructure Projects (proponent: Municipal Engineers Association); and the Class EA for Provincial Transportation Facilities (proponent: Ontario's Ministry of Transportation) are used (MECP, 2018; MTO, 2000).

In Ontario the ESA provides protection for Endangered and Threatened species and their habitat by restricting activities that may negatively affect them (MNRF, 2018). For projects to proceed through an area that has been identified as the habitat of a Threatened or Endangered species, the proponent must receive an authorization that most often requires them to implement mitigation measures (MNRF, 2018). In the case of road projects that are increasing fragmentation, mitigation through the creation of a wildlife crossing structure has been used (Gunson et al., 2018).

Figure 12: Simplified chart indicating evaluated policy's generalized interaction with development of road projects

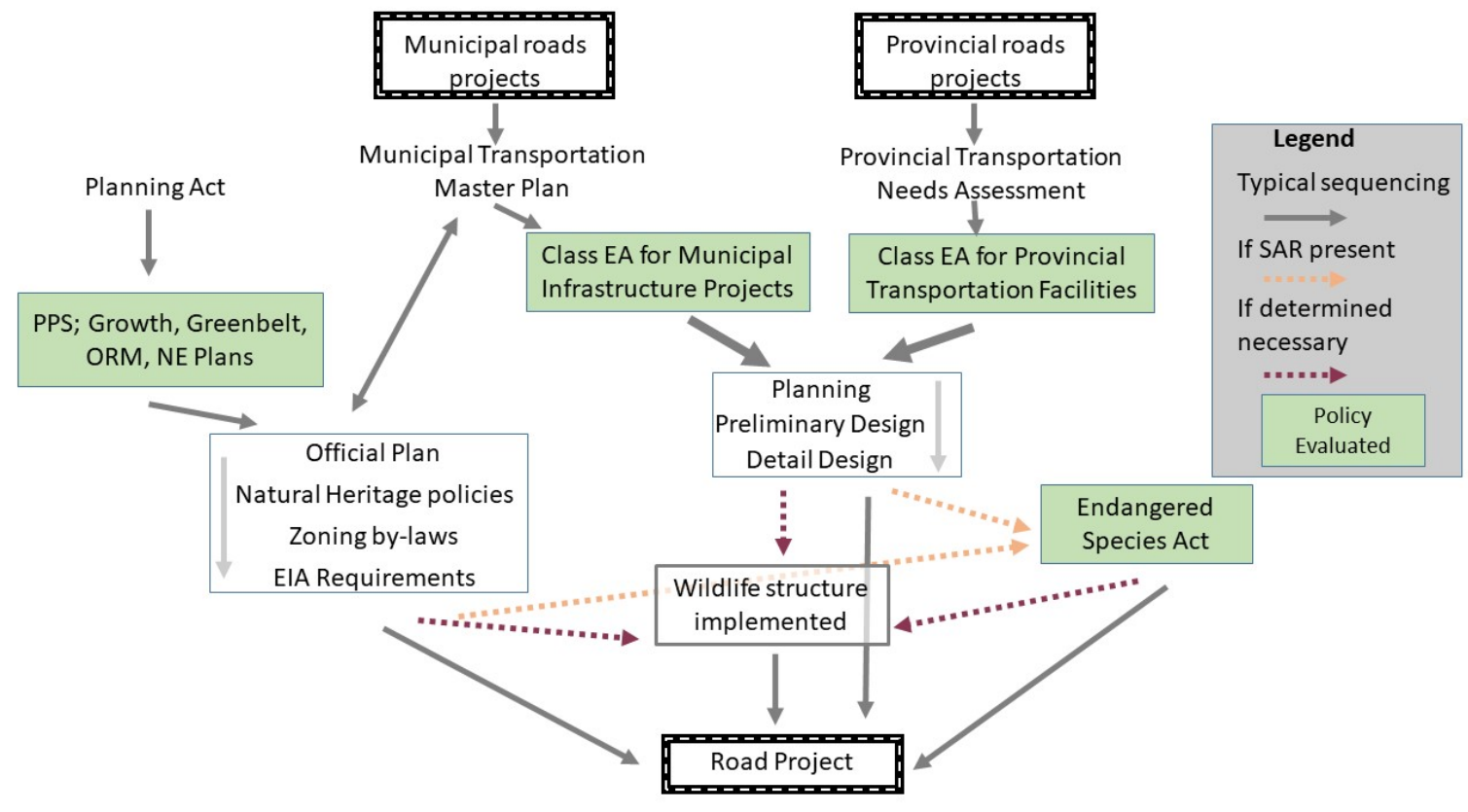

\subsection{Targets, policies, and implementation gap}

The Ontario Biodiversity Strategy outlines an approach to effectively implement appropriate policies and to base decision-making on sound science and the precautionary principle (OBC, 2011). In working to achieve the Strategy's targets, the Province of Ontario has begun to incorporate landscape connectivity principles into the various policies that guide and regulate road projects to address their historic influence in fragmenting landscapes. To counteract the scale of negative impacts of transportation infrastructure the policy response that is needed must include integrated decision-making from across disciplines integrating research, conservation, planning, and education (Lister et al., 2015). 
The Environmental Commissioner of Ontario released a Special Report in 2012 outlining the failures of various ministries in implementing, or even being aware of how their mandates interact with the Province's biodiversity commitments (ECO, 2012). While policy action has been taken since the 2012 Report was published, it is unclear how effective provincial policies have been in addressing the impacts of roads in fragmenting natural habitat and its effect on biodiversity decline. 


\subsection{Methods and methodology}

This MRP uses a multi-methodological qualitative approach to address the following research question and objectives:

Research question:

To what extent are the policies that guide the planning and design of roads, and the protection/recovery of biodiversity integrating Ontario's biodiversity commitments that support landscape connectivity (and wildlife crossing structures) into southern Ontario and GGH road projects?

\section{Research objectives:}

1) To identify key Ontario policies that intersect both road projects and biodiversity recovery;

2) to establish evaluation criteria that link the Ontario Biodiversity Strategy commitments to conservation approaches that focus on landscape connectivity and promoting wildlife crossing structures;

3) to evaluate effectiveness of selected policies in meeting established biodiversity commitments and promoting landscape connectivity in road projects; and

4) to provide context for future discussions around how to improve Ontario's policy framework to better integrate biodiversity values into the planning and design of Ontario's roads as the GGH continues to rapidly urbanize.

This section will outline the research methods and policy evaluation methodology that was used to inform this analysis. The methods employed, and the design of the following methodology enables a pragmatic analysis of existing policy that evaluates effectiveness as it related to the research question.

\subsection{Primary research}

Primary research, in the form of interviews with expert practitioners, represented the starting point for the development of this MRP. The use of "specialized" interviews was used, as this method is identified as appropriate to collect insight on projects and policy application where little identified documentation/literature exists (Patton et al., 2013). Through this approach, insights from Ontariobased expert practitioners was gleaned to gain a basis for evaluation of policy effectiveness.

The expert practitioner interviews for this MRP was supported by funding through a Partnership Development Grant of the Social Sciences and Humanities Research Council of Canada (SSHRC), held by Prof. Nina-Marie Lister through the Ecological Design Lab at Ryerson University. The expert practitioners were asked questions that focused on public decision-making processes. The information gathered from this source focused on factual and technical information, historical context and professional expertise. For this reason, the Research Ethics Board at Ryerson University determined that the project Safe Passage: Towards and Integrated Planning Approach for Landscape Connectivity did not require ethics review or approval to conduct these interviews (Lavalee, pers. com., Dec 20, 2016).

The use of expert interviews as a method for information gathering followed the approach outlined by King \& Horrocks (2010) and included the following elements:

- Sample: interviews were selectively sought with practitioners from across Ontario that have been involved with the planning, implementation or monitoring of projects associated with the creation of wildlife crossing structures. 
- Recruitment of experts: a 'snowball' recruitment method was used. This involved the early identification of key practitioners known to staff at the Ecological Design Lab and then the request that they recommend other potential participants. This was deemed appropriate as practitioners familiar with the intersections between biodiversity conservation and road projects remains tightly defined.

- Interview guide: The interview guide was developed by staff in the Ecological Design Lab and iteratively revised and refined to tease out key themes and probe at desired information (full interview guide: Appendix 2)

- Interview setting: The interviews were conducted over the phone and involved two graduate research assistants, one who took notes and the other who led the interview. The interviews ranged from approximately 40 minutes to an hour and 15 minutes.

Practitioners with expertise and experience in planning, ecology, environmental sciences, Environmental Assessments (EA), and community organizing were interviewed. These practitioners were selected as they have had first hand experience in road projects that have included wildlife crossing structures and were able to share their perspectives on the policy framework and its effectiveness.

The results of the primary research include 11 interviews conducted (including three group interviews) with 15 practitioners from across Ontario, between March and July, 2018. This included 8 municipal and provincial government officials, 3 consultants/private sector professionals, 2 participants from Conservation Authorities, and 2 participants from non-governmental organizations (Table 5). These interviews revealed an important starting point for the identification of key elements of the Policy Analysis Methodology (Sec 3.3).

Table 6: Ontario expert practitioners interviewed for MRP

\begin{tabular}{|l|l|l|l|}
\hline Expert interviewed & Field of experience & Position/field & Organization \\
\hline Kari Gunson & Ecology & Consultant & EcoKare \\
\hline Mandy Karch & Ecology & NGO & $\begin{array}{l}\text { Ontario Road Ecology } \\
\text { Group }\end{array}$ \\
\hline Brenda Carruthers & Planning/policy & Government & MTO \\
\hline Jaclyn Charlton & Planning/EA & Government & MTO \\
\hline $\begin{array}{l}\text { Peter Andrew- } \\
\text { McBride }\end{array}$ & Environmental sciences & Consultant & Wood PLC \\
\hline Megan Hazell & Biology & Consultant & Wood PLC \\
\hline Terri Rogers & Planning/EA & Government & MTO \\
\hline Andrew Healy & Planning/EA & Government & MTO \\
\hline Gillian Dagg-Foster & Planning/EA/Engineering & Government & MTO \\
\hline Joe Crowley & Ecology & Government & MNRF \\
\hline Rick Levick & Community organizing & NGO & $\begin{array}{l}\text { Long Point World } \\
\text { Biosphere Reserve } \\
\text { Foundation }\end{array}$ \\
\hline April Nix & & & City of Guelph \\
\hline Leah Lefler & Planning & Government & City of Guelph \\
\hline Jackie Scott & Planning & Government & $\begin{array}{l}\text { Central Lake Ontario } \\
\text { Conservation Authority }\end{array}$ \\
\hline
\end{tabular}




\begin{tabular}{|l|l|l|l|}
\hline Namrata Shrestha & Ecology & Conservation Authority & $\begin{array}{l}\text { Toronto and Region } \\
\text { Conservation Authority }\end{array}$ \\
\hline
\end{tabular}

\subsection{Secondary research}

Secondary research was used to provide background on the intersecting disciplines that link road projects to biodiversity conservation. The main purpose of the secondary research was to inform the development of evaluation criteria to ensure a robust evaluation framework that was based on academic literature and international, national, and provincial biodiversity commitments. This approach helped to identify specific criteria that covered policy administration, enforcement, scope, effectiveness, and implementation.

Literature that was reviewed included an investigation of conservation responses to biodiversity declines in developed regions. This included an in-depth examination of literature in the fields of landscape ecology (including landscape connectivity and landscape resilience) and road ecology, with a focus on their overlap with land use planning, policy development and decision-making.

The secondary research also included an examination of international biodiversity conventions ratified by Canada through the UN CBD, including the most recent Aichi Biodiversity Targets. In Ontario these international targets have been customized through the work of the Ontario Biodiversity Council and Ministry of Natural Resources and Forestry. Documents and reports generated to guide and analyze Ontario's Aichi implementation were reviewed to inform evaluation criteria development.

Policy research was undertaken to reinforce and elaborate on the feedback received during the expert practitioner interviews. This included an examination of identified polices, associated guidance documents developed by governmental agencies, and grey literature that has offered commentary on the implementation of the identified policies.

\subsection{Policy analysis methodology}

The six-step policy analysis methodology, outlined below, was developed to provide a defensible means of evaluating the policy framework that guides road projects and identify its effectiveness in meeting Ontario's biodiversity commitments and reconnecting landscapes around roads.

This evaluation is primarily based off the Policy Analysis and Program Evaluation frameworks presented in Patton et al. (2013), Irwin (2003), and Bardach (2012). These methods were reviewed and adapted to inform a transparent, valid, useful and feasible analysis. Additional inspiration was supplemented by perspectives gleaned from Nagel (2012), Majchrczak \& Marcus (2014), Burch \& Heinrich (2016), and Dunn (2012). The multi-criteria Program Evaluation process outlined in the manual developed by Communities and Local Government UK (2009) was relied upon to help bridge the gap between traditional policy development and post hoc evaluations.

This analysis was conducted as a retrospective (post hoc/ex post) analysis, which employed a multicriteria (multi-attribute) evaluation to examine existing policies and their implementation. The use of this framework is intended to help achieve a level of objective rationality in the analysis that is based on careful reasoning, logic and empirical observation (Irwin, 2003). 
The analysis outlined in section 4.0 will follow a five-step approach (Figure 11):
1) Define the problem
2) Criteria identification
3) Policy identification
4) Multi-criteria analysis: Comparative matrix
5) Multi-criteria analysis: Scoring policy effectiveness
6) Assessment of strengths and weaknesses

Figure 13: Policy analysis methodology

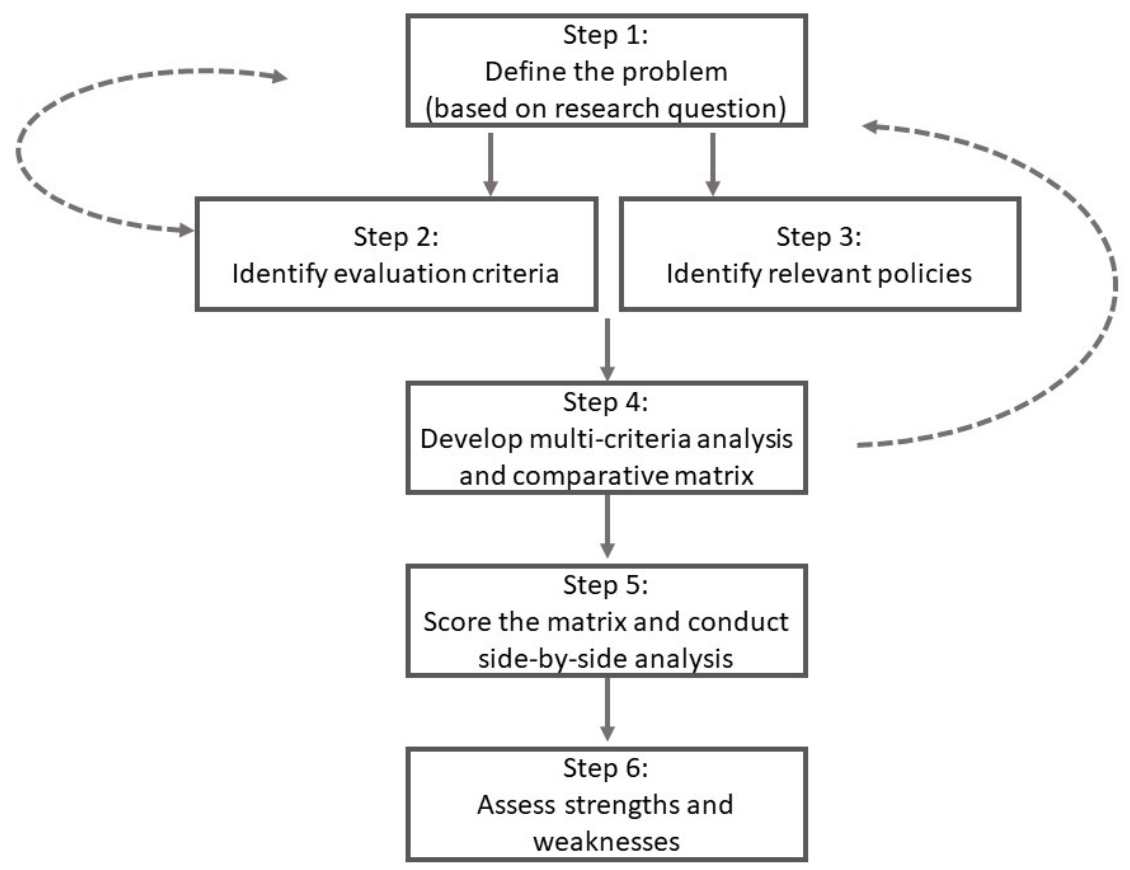

\subsubsection{Define the problem}

The first step of this policy analysis was to define the problem informed by the MRP's research question. This problem definition (Section 4.1) is the starting point of the analysis, outlining the scope and framing the identification of the criteria and policies. By defining the problem, the analysis is given direction helping to reduce irrelevant considerations and create a focus on the central elements of an issue (Patton et al., 2013; Bardach, 2012). The problem definition is intentionally framed in a manner where it can be resolved and assessed (Patton et al., 2013).

The following steps, based on Patton et al., 2013, were undertaken in developing the final problem statement as outlined in Section 4.1:

1) Delineate the boundaries of the problem

- Identify the geographic extent for review.

2) Assumptions

- Identify historic trends to inform potential future conditions of the problem. 


\section{3) List goals and objective}

- Goals and objectives that lead to effective integration of biodiversity considerations in future road projects were defined by the project team to inform the evaluation criteria.

4) Finalize the problem definition

- Iterative process revisited throughout stages within the policy analysis.

\subsubsection{Criteria identification}

The second step of this analysis involved the identification of criteria that could be used to consistently compare the identified policies (Patton et al., 2013). Expert practitioner interviews and secondary research were used to identify appropriate criteria and rationalize their usage in this analysis (identified in Table 6 and outlined in Section 4.2). The evaluation criteria were developed to build a framework that will help to answer the research question and compare the effectiveness of identifies policies (Patton et al., 2013). The criteria act as measures of performance by which the identified policies are judged, and how their evaluation occurs (Table 6) (C\&LG, 2009).

Table 7: Criteria developed to compare and evaluate selected policy

\begin{tabular}{|l|}
\hline Evaluation criteria \\
\hline How does the policy work?/ When is the policy applied? \\
\hline Scope/scale of policy application \\
\hline Policy trigger \\
\hline Decision making \\
\hline Agency collaboration \\
\hline Does the policy integrate OBS Target \# $\mathbf{5}$ (policies integrate biodiversity values)? \\
\hline Biodiversity values in development process \\
\hline Biodiversity values in decision-making \\
\hline Approach to biodiversity impacts \\
\hline Guidance and resources \\
\hline $\begin{array}{l}\text { Does the policy integrate OBS Target \#12 \& \#13 (policies and plans include/protect natural heritage } \\
\text { systems and 'well connected networks')? }\end{array}$ \\
\hline Connectivity commitment/requirements \\
\hline Wildlife crossing structures \\
\hline Has the policy helped create wildlife crossing structures? \\
\hline Wildlife crossing in action \\
\hline External barriers \\
\hline Policy barriers \\
\hline Monitoring \\
\hline
\end{tabular}

\subsubsection{Policy identification}

The third step, running concurrently to the criteria identification was the selection of existing policies to be included in this retrospective analysis. Relevant policies were selected (identified in Table 7 and outlined in Section 4.2) through primary and secondary research. The policies selected for evaluation are those that either expert practitioners identified as aiming to promote landscape connectivity, or that literature outlined in the delivery of wildlife crossing structure projects. 
Table 8: Policies identified for analysis

\begin{tabular}{|l|}
\hline Land use planning policies \\
\hline Provincial Policy Statement, 2014 \\
\hline Growth Plan for the Greater Golden Horseshoe, 2017 \\
\hline Greenbelt Plan, Oak Ridges Moraine Conservation Plan, Niagara Escarpment Plan, 2017 \\
\hline Regulatory policies \\
\hline Class EA for Provincial Transportation Facilities \\
\hline Class EA for Municipal Infrastructure Projects \\
\hline Endangered Species Act \\
\hline
\end{tabular}

\subsubsection{Multi-criteria analysis: comparative matrix}

The fourth step of this method was to develop a multi-criteria analysis to compare and evaluate the selected policies and their approach to the identified criteria. A multi-criteria analysis was determined appropriate as this system is designed to analyze policies against defined criteria (Mark \& Henry, 2011; CLGUK, 2009). This process seeks to generate new ideas or test theories around a known problem, in this case habitat fragmentation caused by roads (Mark \& Henry, 2011).

A comparative matrix was created to summarize and visualize the analysis. It is set up with the selected policies along one axis, and the criteria along the opposite axis. This method did not apply discretionary weighting to rank each criterion, but rather has employed a side-by-side analysis that visually identifies each policy's impact related to the stated criteria (outlined in Section 4.3). The template matrix is then populated with qualitative responses to the evaluation questions that are associated with each established criteria. These qualitative responses indicate the approach or effectiveness of each policy in addressing the criteria.

This method was deemed favourable as the identified criteria within the matrix may contain higher or lower value for various readers and policy analysts. Each policy is compared against these criteria allowing for a descriptive qualitative analysis to be conducted (Patton, et al., 2013).

\subsubsection{Multi-criteria analysis: scoring policy effectiveness}

The fifth step of this method focused on the analysis of the evaluated policies and aimed to initiate the identification of strengths and weaknesses as they relate the criteria evaluated. This process was undertaken by reflecting on the completed comparative matrix and employing a Goeller Scorecard approach to display evaluation (Patton et al., 2013).

The Goeller Scorecard, as outlined in Patton et al. (2013) is used to add additional analysis to the comparative matrix. The scorecard displays the relative strengths and weaknesses of each policy as it related to the criterion. This scorecard method applies value judgements to the approach of each policy as it relates to the criteria.

The values/scores were developed by the author and were based on the stated research question and objectives of this MRP. This scorecard was used to display how each policy's approach to the identified criteria either promotes or detracts from the goals of promoting landscape connectivity and biodiversity recovery as it related to road projects. These scores were determined though insights from the expert practitioner interviews and secondary research. 


\subsubsection{Assessment of policy strengths and weaknesses}

The final step of this method was to assess the multi-criteria analysis (comparison matrix and associated scorecard) to determine the various policy's effectiveness with respect to biodiversity recovery and landscape connectivity. The relative strengths and weaknesses were considered by the author and summarized. The policy evaluation involved identifying reflections from the expert practitioner interviews and the secondary research. 


\subsection{Policy analysis}

The following policy analysis was conducted to explore the intersection of road projects and biodiversity protection. This analysis is designed to review Ontario policies that have an important role to play in helping to improve landscape connectivity around roads, and to evaluate their effectiveness in achieving targets set out in Ontario's Biodiversity Strategy. The analysis seeks to answer this MRP's research question and help to identify a path forward in Ontario to ensure relevant policy effectively addresses habitat fragmentation to help protect and recover biodiversity.

This policy analysis has employed a six-stage process, outlined in section 3.0 consisting of: 1) definition of the problem; 2) criteria identification; 3) policy identification; 4) multi-criteria analysis: comparative matrix; 5) multi-criteria analysis: scoring policy effectiveness; 6 ) assessment of strengths and weaknesses.

\subsection{Problem statement}

The starting point of this analysis stems from the Environmental Commissioner of Ontario's statement that the loss of biodiversity across Ontario and around the world have reached "crisis" levels (ECO, 2016). As demonstrated through the literature reviewed in Section 2.0, this statement is well substantiated in academic literature and the ongoing expansion of road networks associated with urbanization is further exacerbating the pressures felt by many Ontario species.

\section{Problem Statement:}

- Biodiversity values have historically been left out of the planning, design and construction of road projects in Ontario;

- The Province is rapidly approaching the Ontario Biodiversity Strategy's 2020 target deadlines and the planning and design of provincial and municipal roads have inconsistently integrated measures to improve landscape connectivity and biodiversity recovery;

Parameters of the problem statement (for the purposes of this analysis):

- Boundaries: southern Ontario and the GGH.

- Assumptions: rapid and ongoing urbanization in the defined boundaries will lead to the expansion of and improvements to the road network.

- Goal of policy evaluation is to answer the MRP's research question:

o To what extent are the policies that guide the planning and design of roads, and the protection/recovery of biodiversity integrating Ontario's biodiversity commitments that support landscape connectivity (and wildlife crossing structures) into southern Ontario and $\mathrm{GGH}$ road projects?

- Objectives of the policy evaluation (as identified in Section 1.3):

o To identify key Ontario policies that intersect both road projects and biodiversity recovery;

0 to establish evaluation criteria that link the commitments that the Ontario Biodiversity Strategy commitments to conservation approaches that focus on landscape connectivity and promoting wildlife crossing structures;

0 to evaluate effectiveness of selected policies in meeting established biodiversity commitments and promoting landscape connectivity in road projects; and 
0 to provide context for future discussions around how to improve Ontario's policy framework to better integrate biodiversity values into the planning and design of Ontario's roads as the GGH continues to rapidly urbanize.

\subsection{Criteria evaluated}

The criteria used to evaluate the problem were identified to assess the relative strengths and weaknesses of the identified policies. A set of 14 criteria were used to evaluate each policy and their effectiveness in integrating Ontario Biodiversity Strategy (OBS) targets that relate to landscape connectivity and roads. The criteria are grouped by the following key questions:

- How does the policy work?/ When is the policy applied?

- Does the policy appropriately integrate OBS Target \# 5 (policies integrate biodiversity values)?

- Does the policy appropriately integrate OBS Target \#12 \& \#13 (policies and plans include/protect natural heritage systems and 'well connected networks')?

- Has the policy helped create wildlife crossing structures?

The evaluation criteria are as follows:

\section{Group 1: How does the policy work?/ When is the policy applied? Scope/scale of policy application}

This examines if interviewed expert practitioners or secondary research have identified: from an administrative standpoint, the approach a policy takes to planning/evaluation/regulation. Landscape connectivity and biodiversity recovery benefits from a broad ecological focus to better understand broad landscape patterns more complex natural systems (Turner, 2005). Policy aiming to recover biodiversity is determined to be most effective when decision-making includes a landscape-scale perspective, over a narrower project-based scope.

\section{Policy Trigger}

This examines if interviewed expert practitioners or secondary research have identified: from an administrative standpoint, when and how the policy is implemented. Through the proliferation of Ontario's road network, a highly fragmented natural landscape was the unintended side effect (OBC, 2015). Policy that proactively identifies landscape connectivity ahead of potential projects is determined to be most effective in biodiversity recovery.

\section{Decision making}

This examines if interviewed expert practitioners or secondary research have identified: from an administrative standpoint, who or what agency implements the policy and makes the decision on whether or not a project has meet stated conditions to proceed. This was deemed helpful to better understand the context of decision making, but no agency was determined more or less effective in biodiversity recovery.

\section{Agency Collaboration}

This examines if interviewed expert practitioners or secondary research have identified: whether the policy, its language or implementation requires or promotes collaboration amongst levels of 
governments or agencies sharing similar (or overlapping) mandates. In Ontario more than 60 statutes, regulations, and government policies can be relevant to Ministry of Transportation road projects (MTO, 2014) and additional policy considerations must be integrated in municipal road projects. These policies are implemented by various agencies and levels of government and can cause competing and overlapping mandates. Policy that leads to interagency collaboration is determined to be more effective in promoting biodiversity recovery.

\section{Group 2: Does the policy integrate OBS Target \# 5 (policies integrate biodiversity values)? Biodiversity values in development process}

This examines if interviewed expert practitioners or secondary research have identified: how, and at what stage biodiversity values are considered in the development process of road project. This criteria helps to evaluate how OBS Target \#5 is being integrated or applied in the application of a policy (OBS, 2011). Policy that integrates biodiversity values in the earliest stages of planning and design are determined to be more effective compares with policies that only integrate biodiversity values in the later stages (permitting/approval) of road projects.

\section{Biodiversity values in decision-making}

This examines if interviewed expert practitioners or secondary research have identified: how, and at what stage biodiversity values are considered in the decision making around road projects. This criteria helps to evaluate how OBS Target \#5 is affecting decision-making (OBS, 2011). Policy that integrates biodiversity values in to final decision-making is determined to be effective in promoting biodiversity recovery.

\section{Approach to biodiversity impacts}

This examines if interviewed expert practitioners or secondary research have identified: how the policy has been applied to address the negative impact of roads to biodiversity, either by aiming to avoid impact or rather by working to mitigate impacts. The negative impacts of roads to wildlife can be reduced by avoiding viable and valuable habitat through siting (avoiding habitat), design (enhancing connectivity) and management (mitigating damage) (Hadad, 2015). Policy that approaches biodiversity impacts from a perspective that primarily aims to avoid known habitat is determined to be more effective than those that rely on mitigation once negative impact has occurred.

\section{Guidance and resources}

This examines if interviewed expert practitioners or secondary research have identified: if and how effectively additional resources and guidance documents have been developed in order to help integrate biodiversity values in to road projects. A key action in Ontario's Biodiversity Strategy states the need to develop "decision-making tools for effective biodiversity conservation" (OBS, 2011). Policy with associated guidance document that guide how to integrate biodiversity values around landscape connectivity into road projects is determined to be effective in helping achieve OBS Target \#5.

Group 3: Does the policy integrate OBS Target \#12 \& \#13 (policies and plans include/protect natural heritage systems and 'well connected networks')? Connectivity commitment/requirements 
This examines if interviewed expert practitioners or secondary research have identified: whether there is a policy commitment to protect natural heritage systems or well-connected networks for biodiversity. Connectivity is acknowledged as a core tenant of biodiversity recovery as it supports the safe passage of mobile fauna (Beckmann \& Hilty, 2014). Policy that mandates or ensures that natural heritage systems or networks of connected habitat are identified, protected and enhanced is determined to be a necessary component to achieve both OBS Targets \#12 and \#13.

\section{Wildlife crossing structures}

This examines if interviewed expert practitioners or secondary research have identified: whether the policy or guidance documents (if developed) specifically identify the use of wildlife crossing structures to improve landscape connectivity around roads. The integration of wildlife crossing structures has been found successful in reducing impacts of roads for mobile species (Lister et al., 2015). Policy and guidance documents that identify the use of wildlife crossing projects to improve landscape connectivity is determined to be a valuable component to implementing OBS Target 12 and 13.

\section{Group 4: Has the policy helped create wildlife crossing structures?}

Wildlife crossing in action

This examines if interviewed expert practitioners or secondary research have identified: whether the policy's implementation has led to the creation of wildlife crossing structure projects. Policy that leads to on-the-ground changes that are intended to reconnect the landscape around roads is determined to be effective in promoting biodiversity recovery.

\section{External barriers}

This examines if interviewed expert practitioners or secondary research have identified: whether barriers to implementation have been cited as the cause for not implementing wildlife crossing structures in a road project. The perceived and the actual expense of wildlife crossing structures has been reported to hinder their widespread implementation (ARC, n.d.). Other external barriers include a lack of communication amongst agencies or a gap in knowledge around biodiversity commitments and the value of improving landscape connectivity. Policy that addresses barriers that disrupt the implementation of wildlife crossing structures is determined to be effective in promoting biodiversity recovery.

\section{Policy barriers}

This examines if interviewed expert practitioners or secondary research have identified: whether there are circumstances where the policy can interfere with the creation of wildlife crossing structures. Due to the complex policy landscape there may be unintended consequence of competing policies that hinder the ability to improve landscape connectivity. Policy that does not interferes with the creation of wildlife crossing structures is determined to be effective in promoting biodiversity recovery.

\section{Monitoring}

This examines if interviewed expert practitioners or secondary research have identified: whether the policy ensures biodiversity-related monitoring is a condition of a road project that included some element of wildlife crossing structures. The Ontario Biodiversity Strategy states the research and monitoring is essential to achieving biodiversity goals (OBS, 2011). Policy that ensures long-term 
monitoring of projects designed to improve landscape connectivity is determines to be effective in promoting biodiversity recovery.

\subsection{Policy identification}

Nine policies have been identified by expert practitioners and determined appropriate by the author for this analysis and evaluation. These polices were identified as having an important overlap between road projects and biodiversity recovery. These policies were most often mentioned or sited by expert practitioners when describing the implementation of policies that consider wildlife connectivity or when describing successful examples of the implementation of wildlife crossing structures (outlined in Sec 3.1 \& 3.3.3).

The identified policies have been organized in "Table 9: Policies evaluated". Land use planning policies were identified by $10 / 14$ of the interviewed practitioners as having an important role in promoting landscape connectivity and guiding road projects. Regulatory policies were identified 9/14 of the expert practitioners. Three of the land use policies (Greenbelt Plan, Oak Ridges Moraine Conservation Plan and Niagara Escarpment Plan) having been grouped together in this analysis, due to their similar approaches.

Table 9: Policies identified for analysis with sources

\begin{tabular}{|c|c|}
\hline Land use planning policies & Sources \\
\hline $\begin{array}{l}\text { Provincial Policy Statement, } 2014 \\
\text { (implemented through municipal Official Plans) }\end{array}$ & $\begin{array}{l}\text { K. Gunson; M. Karch; B. Carruthers; J. Charlton, P. } \\
\text { Andrew-McBride, M. Hazell; A. Nix, L. Lefler; J. Scott }\end{array}$ \\
\hline $\begin{array}{l}\text { Growth Plan for the Greater Golden } \\
\text { Horseshoe, } 2017\end{array}$ & M. Karch; J. Crowley \\
\hline $\begin{array}{l}\text { Greenbelt Plan, Oak Ridges Moraine } \\
\text { Conservation Plan, Niagara Escarpment Plan, } \\
2017\end{array}$ & K. Gunson; M. Karch; J. Crowley; A. Nix, L. Lefler \\
\hline \multicolumn{2}{|l|}{ Regulatory policies } \\
\hline Class EA for Provincial Transportation Facilities & $\begin{array}{l}\text { B. Carruthers; J. Charlton, P. Andrew-McBride, M. } \\
\text { Hazell; G. Dagg-Foster; A. Nix, L. Lefler }\end{array}$ \\
\hline Class EA for Municipal Infrastructure Projects & A. Nix, L. Lefler \\
\hline Ontario Endangered Species Act & $\begin{array}{l}\text { B. Carruthers; J. Charlton, P. Andrew-McBride, M. } \\
\text { Hazell; G. Dagg-Foster; J. Crowley; R. Levick }\end{array}$ \\
\hline
\end{tabular}

These policies were further investigated to assess how they address the identified criteria through a review of associated literature, guidance documents, plans and policy structures. A summary of the six policies (grouping Greenbelt Plan, Oak Ridges Moraine Conservation Plan and Niagara Escarpment Plan as one) is outlined in Appendix C.

\subsection{Multi-criteria analysis: comparative matrix}

The evaluation criteria used for this analysis is outlined in "Table 10: Evaluation criteria and categories for comparison", and compares the policies approaches and effectiveness against each of the selected criteria. In order to assist the reading of the multi-criteria analysis table consistent categories were developed and indicated in Table 10. 
Table 10: Evaluation criteria and categories for comparison

\begin{tabular}{|c|c|}
\hline Evaluation criteria & Categories for matrix \\
\hline \multicolumn{2}{|c|}{ How does the policy work?/ When is the policy applied? } \\
\hline Scope/scale of policy application & $\begin{array}{l}\text { - project-based } \\
\text { - landscape-scale }\end{array}$ \\
\hline Policy trigger & $\begin{array}{l}\text { - Long-term/community planning } \\
\text { - Provincial or municipal road project } \\
\text { - Presence of Species at Risk }\end{array}$ \\
\hline Decision making & $\begin{array}{l}\text { - Minister } \\
\text { - Agency } \\
\text { - Pre-approved } \\
\text { - Regulation by rule } \\
\text { - Permit } \\
\text { - other body }\end{array}$ \\
\hline Agency collaboration & $\begin{array}{l}\text { - formal } \\
\text { - informal } \\
\text { - none }\end{array}$ \\
\hline \multicolumn{2}{|c|}{ Does the policy integrate OBS Target \# 5 (policies integrate biodiversity values)? } \\
\hline Biodiversity values in development process & $\begin{array}{l}\text { - not considered } \\
\text { - early/middle stage } \\
\text { - late stage }\end{array}$ \\
\hline Biodiversity values in decision-making & $\begin{array}{l}\text { - must be addressed } \\
\text { - must be considered } \\
\text { - should be considered } \\
\text { - not mentioned }\end{array}$ \\
\hline Approach to biodiversity impacts & $\begin{array}{l}\text { - preventative } \\
\text { - avoidance } \\
\text { - mitigative } \\
\text { - compensation }\end{array}$ \\
\hline Guidance and resources & $\begin{array}{l}\text { - yes } \\
\text { - no }\end{array}$ \\
\hline \multicolumn{2}{|c|}{$\begin{array}{l}\text { Does the policy integrate OBS Target \#12 \& \#13 (policies and plans include/protect natural heritage } \\
\text { systems and 'well connected networks')? }\end{array}$} \\
\hline Connectivity commitment/requirements & $\begin{array}{l}\text { - yes } \\
\text { - no } \\
\text { - uncertain }\end{array}$ \\
\hline Wildlife crossing structures & $\begin{array}{l}\text { - specifically mentioned in policy } \\
\text { - specifically mentioned in guidance } \\
\text { - unknown } \\
\text { - not mentioned }\end{array}$ \\
\hline \multicolumn{2}{|c|}{ Has the policy helped create wildlife crossing structures? } \\
\hline Wildlife crossing in action & $\begin{array}{l}\text {-yes } \\
\text { - no } \\
\text { - unknown } \\
\end{array}$ \\
\hline External barriers & $\begin{array}{l}\text {-yes } \\
\text { - no } \\
\text { - unknown }\end{array}$ \\
\hline
\end{tabular}




\begin{tabular}{|l|l|}
\hline Policy barriers & - yes \\
& - no \\
\hline Monitoring & - Yes \\
& - not required \\
& - depending on circumstances \\
\hline
\end{tabular}

The evaluated policy and criteria informed the population of "Table 11: Comparative matrix". This table identifies all six polies and all 14 criteria with the populated cells indicating the policies approach/impact to each criteria. 
Table 11: Comparative matrix

\begin{tabular}{|c|c|c|c|c|c|c|}
\hline \multirow[t]{3}{*}{ Evaluation criteria } & \multicolumn{6}{|c|}{ Observations recorded through expert practitioner interviews and secondary research } \\
\hline & \multicolumn{3}{|l|}{ Land use planning } & \multicolumn{3}{|c|}{ Regulatory policies } \\
\hline & $\begin{array}{l}\text { PPS } \\
\text { (implemented } \\
\text { through } \\
\text { Municipal } \\
\text { Official Plans) } \\
\end{array}$ & Growth Plan & $\begin{array}{l}\text { Greenbelt, Oak } \\
\text { Ridges Moraine, } \\
\text { Niagara } \\
\text { Escarpment } \\
\text { Plans }\end{array}$ & $\begin{array}{l}\text { Class EA for } \\
\text { Provincial } \\
\text { Transportation } \\
\text { Facilities }\end{array}$ & $\begin{array}{l}\text { Class EA for } \\
\text { Municipal } \\
\text { Infrastructure } \\
\text { Projects }\end{array}$ & $\begin{array}{l}\text { Endangered } \\
\text { Species Act }\end{array}$ \\
\hline \multicolumn{7}{|c|}{ How does the policy work?/ When is the policy applied? } \\
\hline $\begin{array}{l}\text { Scope/scale of policy } \\
\text { application }\end{array}$ & Landscape-scale & Landscape-scale & Landscape-scale & Project-based & Project-based & Project-based \\
\hline Policy trigger & $\begin{array}{l}\text { Long- } \\
\text { term/community } \\
\text { planning }\end{array}$ & $\begin{array}{l}\text { Long- } \\
\text { term/community } \\
\text { planning }\end{array}$ & $\begin{array}{l}\text { Long- } \\
\text { term/community } \\
\text { planning }\end{array}$ & $\begin{array}{l}\text { Provincial road } \\
\text { project (if } \\
\text { deemed } \\
\text { applicable for } \\
\text { Class EA) }\end{array}$ & $\begin{array}{l}\text { Municipal road } \\
\text { project (if } \\
\text { deemed } \\
\text { applicable for } \\
\text { Class EA) }\end{array}$ & $\begin{array}{l}\text { Presence of } \\
\text { individual } \\
\text { Species at Risk } \\
\text { or habitat }\end{array}$ \\
\hline Decision making & $\begin{array}{l}\text { Provincial agency } \\
\text { approval } \\
\text { (MMAH) }\end{array}$ & $\begin{array}{l}\text { Provincial agency } \\
\text { approval } \\
\text { (MMAH) }\end{array}$ & $\begin{array}{l}\text { Provincial agency } \\
\text { approval } \\
\text { (MMAH) }\end{array}$ & $\begin{array}{l}\text { Pre-approved } \\
\text { process (by the } \\
\text { Minister of } \\
\text { MECP) }\end{array}$ & $\begin{array}{l}\text { Pre-approved } \\
\text { process (by } \\
\text { the Minister of } \\
\text { MECP) }\end{array}$ & $\begin{array}{l}\text { - Regulation by } \\
\text { rule (under } \\
\text { ESA } \\
\text { Authorization) } \\
\text { - Permit } \\
\text { (issued by the } \\
\text { Minister of } \\
\text { MECP) }\end{array}$ \\
\hline Agency collaboration & Informal or none & $\begin{array}{l}\text { Formal (in the } \\
\text { creation of } \\
\text { regional NHS) }\end{array}$ & $\begin{array}{l}\text { Formal (in the } \\
\text { creation of } \\
\text { regional NHS) }\end{array}$ & $\begin{array}{l}\text { Formal } \\
\text { (consultation } \\
\text { requirements) }\end{array}$ & $\begin{array}{l}\text { Formal } \\
\text { (consultation } \\
\text { requirements) }\end{array}$ & $\begin{array}{l}\text { - Informal } \\
\text { (registration by } \\
\text { rule) } \\
\cdot \text { Formal } \\
\text { (approval by } \\
\text { MECP for a } \\
\text { permit) }\end{array}$ \\
\hline
\end{tabular}




\begin{tabular}{|c|c|c|c|c|c|c|}
\hline \multicolumn{7}{|c|}{ Does the policy integrate OBS Target \# 5 (policies integrate biodiversity values)? } \\
\hline $\begin{array}{l}\text { Biodiversity values in } \\
\text { development process }\end{array}$ & $\begin{array}{l}\text { early (planning } \\
\text { before } \\
\text { development) }\end{array}$ & $\begin{array}{l}\text { early (planning } \\
\text { before } \\
\text { development) }\end{array}$ & $\begin{array}{l}\text { early (planning } \\
\text { before } \\
\text { development) }\end{array}$ & $\begin{array}{l}\text { early/middle } \\
\text { stage (planning } \\
\text { and design) }\end{array}$ & $\begin{array}{l}\text { early/middle } \\
\text { stage } \\
\text { (planning and } \\
\text { design) }\end{array}$ & $\begin{array}{l}\text { late stage } \\
\text { (permitting) }\end{array}$ \\
\hline $\begin{array}{l}\text { Biodiversity values in } \\
\text { decision-making }\end{array}$ & \begin{tabular}{|l} 
- must be \\
considered (in \\
southern and \\
eastern Ontario) \\
- should be \\
considered (in \\
rest of Ontario) \\
\end{tabular} & $\begin{array}{l}\text { must be } \\
\text { considered }\end{array}$ & $\begin{array}{l}\text { must be } \\
\text { addressed }\end{array}$ & $\begin{array}{l}\text { must be } \\
\text { considered }\end{array}$ & $\begin{array}{l}\text { must be } \\
\text { considered }\end{array}$ & $\begin{array}{l}\text { must be } \\
\text { addressed (if } \\
\text { SAR present) }\end{array}$ \\
\hline $\begin{array}{l}\text { Approach to biodiversity } \\
\text { impacts }\end{array}$ & preventative & preventative & preventative & $\begin{array}{l}\text { avoidance, } \\
\text { mitigation, or } \\
\text { compensation } \\
\end{array}$ & $\begin{array}{l}\text { avoidance, } \\
\text { mitigation, or } \\
\text { compensation } \\
\end{array}$ & $\begin{array}{l}\text { Mitigation or } \\
\text { compensation }\end{array}$ \\
\hline Guidance and resources & Yes & Yes & Yes & Yes & Yes & Yes \\
\hline \multicolumn{7}{|c|}{$\begin{array}{l}\text { Does the policy integrate OBS Target \#12 \& \#13 (policies and plans include/protect natural heritage systems and 'well connected } \\
\text { networks')? }\end{array}$} \\
\hline $\begin{array}{l}\text { Connectivity } \\
\text { commitment/requirements }\end{array}$ & $\begin{array}{l}\text { yes, identification } \\
\text { necessary }\end{array}$ & $\begin{array}{l}\text { yes, protection } \\
\text { necessary }\end{array}$ & $\begin{array}{l}\text { yes, protection } \\
\text { necessary }\end{array}$ & no & no & $\begin{array}{l}\text { uncertain } \\
\text { (identified as a } \\
\text { routine } \\
\text { condition for } \\
\text { some species } \\
\text { at risk) } \\
\end{array}$ \\
\hline Wildlife crossing structures & $\begin{array}{l}\text { specifically } \\
\text { mentioned in } \\
\text { guidance }\end{array}$ & Not mentioned & $\begin{array}{l}\text { Specifically } \\
\text { mentioned in } \\
\text { guidance (for } \\
\text { ORM) }\end{array}$ & unknown & $\begin{array}{l}\text { specifically } \\
\text { mentioned in } \\
\text { guidance }\end{array}$ & $\begin{array}{l}\text { specifically } \\
\text { mentioned in } \\
\text { guidance }\end{array}$ \\
\hline \multicolumn{7}{|c|}{ Has the policy helped create wildlife crossing structures? } \\
\hline Wildlife crossing in action & $\begin{array}{l}\text { yes (indirect and } \\
\text { select cases) }\end{array}$ & unknown & unknown & yes (direct) & yes (direct) & yes (direct) \\
\hline External barriers & $\begin{array}{l}\text { Yes (financial, } \\
\text { community }\end{array}$ & unknown & unknown & $\begin{array}{l}\text { Yes (e.g. data } \\
\text { gaps and } \\
\text { financial cost of }\end{array}$ & $\begin{array}{l}\text { Yes (e.g. data } \\
\text { gaps and } \\
\text { financial cost }\end{array}$ & $\begin{array}{l}\text { Yes (e.g. data } \\
\text { gaps) }\end{array}$ \\
\hline
\end{tabular}




\begin{tabular}{|c|c|c|c|c|c|c|}
\hline & $\begin{array}{l}\text { support } \\
\text { necessary) }\end{array}$ & & & $\begin{array}{l}\text { wildlife crossing } \\
\text { structure) }\end{array}$ & $\begin{array}{l}\text { of wildlife } \\
\text { crossing } \\
\text { structure) }\end{array}$ & \\
\hline Policy barriers & $\begin{array}{l}\text { Yes (EA process } \\
\text { and land use } \\
\text { planning } \\
\text { disconnected) }\end{array}$ & $\begin{array}{l}\text { Yes (EA process } \\
\text { and land use } \\
\text { planning } \\
\text { disconnected) }\end{array}$ & $\begin{array}{l}\text { Yes (EA process } \\
\text { and land use } \\
\text { planning } \\
\text { disconnected) }\end{array}$ & $\begin{array}{l}\text { Yes (e.g. land } \\
\text { ownership } \\
\text { issues beyond } \\
\text { right-of-way) }\end{array}$ & $\begin{array}{l}\text { Yes (e.g. land } \\
\text { ownership } \\
\text { issues beyond } \\
\text { right-of-way) }\end{array}$ & $\begin{array}{l}\text { Yes (e.g. ESA } \\
\text { process can } \\
\text { create hurdle } \\
\text { for } \\
\text { stewardship } \\
\text { work) }\end{array}$ \\
\hline Monitoring & Not required & Not required & Not required & $\begin{array}{l}\text { Yes (during } \\
\text { construction) }\end{array}$ & Yes & $\begin{array}{l}\text { Depending on } \\
\text { authorization } \\
\text { conditions }\end{array}$ \\
\hline
\end{tabular}




\subsection{Scoring policy effectiveness}

To better visualize the evaluation of relative policy effectiveness a Goeller Scorecard approach was used to indicate values given to the categories in the multi criteria evaluation table. "Table 13: Scoring policy effectiveness" is a copy of the multi -criteria analysis table with a coloured qualitative scoring layer added to each cell to indicate the policy's assessed effectiveness as it relates to each criteria. The scoring values were split into four categories, described in "Table 12: Relative effectiveness of policy approach/application". This coloured scorecard indicates from a landscape connectivity and biodiversity recovery perspective the relative effectiveness of each policy as they related to the selected criteria.

Table 12: Relative effectiveness of policy approach/application

\begin{tabular}{|l|l|}
\hline Improving conditions for landscape connectivity & Highly effective \\
\hline $\begin{array}{l}\text { Potentially improving conditions for landscape } \\
\text { connectivity }\end{array}$ & Moderately effective \\
\hline Maintaining conditions for landscape connectivity & Low effectiveness \\
\hline $\begin{array}{l}\text { Potentially decreasing conditions for landscape } \\
\text { connectivity }\end{array}$ & Not effective/hinderance \\
\hline Not assessed or information available & no value assessed \\
\hline
\end{tabular}


Table 13: Scoring policy effectiveness

\begin{tabular}{|c|c|c|c|c|c|c|}
\hline \multirow[t]{3}{*}{ Evaluation criteria } & \multicolumn{6}{|c|}{ Observations recorded through expert practitioner interviews and secondary research } \\
\hline & \multicolumn{3}{|l|}{ Land use planning } & \multicolumn{3}{|c|}{ Regulatory policies } \\
\hline & $\begin{array}{l}\text { PPS } \\
\text { (implemented } \\
\text { through } \\
\text { Municipal } \\
\text { Official Plan) } \\
\end{array}$ & Growth Plan & $\begin{array}{l}\text { Greenbelt, Oak } \\
\text { Ridges Moraine, } \\
\text { Niagara } \\
\text { Escarpment } \\
\text { Plans }\end{array}$ & $\begin{array}{l}\text { Class EA for } \\
\text { Provincial } \\
\text { Transportation } \\
\text { Facilities }\end{array}$ & $\begin{array}{l}\text { Class EA for } \\
\text { Municipal } \\
\text { Infrastructure } \\
\text { Projects }\end{array}$ & $\begin{array}{l}\text { Endangered } \\
\text { Species Act }\end{array}$ \\
\hline \multicolumn{7}{|c|}{ How does the policy work?/ When is the policy applied? } \\
\hline $\begin{array}{l}\text { Scope/scale of policy } \\
\text { application }\end{array}$ & Landscape-scale & Landscape-scale & Landscape-scale & Project-based & Project-based & Project-based \\
\hline Policy trigger & $\begin{array}{l}\text { Long- } \\
\text { term/community } \\
\text { planning }\end{array}$ & $\begin{array}{l}\text { Long- } \\
\text { term/community } \\
\text { planning }\end{array}$ & $\begin{array}{l}\text { Long- } \\
\text { term/community } \\
\text { planning }\end{array}$ & $\begin{array}{l}\text { Provincial road } \\
\text { project (if } \\
\text { deemed } \\
\text { applicable for } \\
\text { Class EA) } \\
\end{array}$ & $\begin{array}{l}\text { Municipal road } \\
\text { project (if } \\
\text { deemed } \\
\text { applicable for } \\
\text { Class EA) }\end{array}$ & $\begin{array}{l}\text { Presence of } \\
\text { individual } \\
\text { Species at Risk } \\
\text { or habitat }\end{array}$ \\
\hline Decision making & $\begin{array}{l}\text { Provincial agency } \\
\text { approval } \\
\text { (MMAH) }\end{array}$ & $\begin{array}{l}\text { Provincial agency } \\
\text { approval } \\
\text { (MMAH) }\end{array}$ & $\begin{array}{l}\text { Provincial agency } \\
\text { approval } \\
\text { (MMAH) }\end{array}$ & $\begin{array}{l}\text { Pre-approved } \\
\text { process (by the } \\
\text { Minister of } \\
\text { MECP) }\end{array}$ & $\begin{array}{l}\text { Pre-approved } \\
\text { process (by } \\
\text { the Minister of } \\
\text { MECP) }\end{array}$ & $\begin{array}{l}\text { - Regulation by } \\
\text { rule (under } \\
\text { ESA } \\
\text { Authorization) } \\
\cdot \text { Permit } \\
\text { (issued by the } \\
\text { Minister of } \\
\text { MECP) }\end{array}$ \\
\hline Agency collaboration & Informal or none & $\begin{array}{l}\text { Formal (in the } \\
\text { creation of } \\
\text { regional NHS) }\end{array}$ & $\begin{array}{l}\text { Formal (in the } \\
\text { creation of } \\
\text { regional NHS) }\end{array}$ & $\begin{array}{l}\text { Formal } \\
\text { (consultation } \\
\text { requirements) }\end{array}$ & $\begin{array}{l}\text { Formal } \\
\text { (consultation } \\
\text { requirements) }\end{array}$ & $\begin{array}{l}\text { - Informal } \\
\text { (registration by } \\
\text { rule) } \\
\text { - Formal } \\
\text { (approval by } \\
\text { MECP for a } \\
\text { permit) }\end{array}$ \\
\hline
\end{tabular}




\begin{tabular}{|c|c|c|c|c|c|c|}
\hline \multicolumn{7}{|c|}{ Does the policy integrate OBS Target \# 5 (policies integrate biodiversity values)? } \\
\hline $\begin{array}{l}\text { Biodiversity values in } \\
\text { development process }\end{array}$ & $\begin{array}{l}\text { early (planning } \\
\text { before } \\
\text { development) }\end{array}$ & $\begin{array}{l}\text { early (planning } \\
\text { before } \\
\text { development) }\end{array}$ & $\begin{array}{l}\text { early (planning } \\
\text { before } \\
\text { development) }\end{array}$ & $\begin{array}{l}\text { early/middle } \\
\text { stage (planning } \\
\text { and design) }\end{array}$ & $\begin{array}{l}\text { early/middle } \\
\text { stage } \\
\text { (planning and } \\
\text { design) }\end{array}$ & $\begin{array}{l}\text { late stage } \\
\text { (permitting) }\end{array}$ \\
\hline $\begin{array}{l}\text { Biodiversity values in } \\
\text { decision-making }\end{array}$ & $\begin{array}{l}\text { - must be } \\
\text { considered (in } \\
\text { southern and } \\
\text { eastern Ontario) } \\
\text { - should be } \\
\text { considered (in } \\
\text { rest of Ontario) }\end{array}$ & $\begin{array}{l}\text { must be } \\
\text { considered }\end{array}$ & $\begin{array}{l}\text { must be } \\
\text { addressed }\end{array}$ & $\begin{array}{l}\text { must be } \\
\text { considered }\end{array}$ & $\begin{array}{l}\text { must be } \\
\text { considered }\end{array}$ & $\begin{array}{l}\text { must be } \\
\text { addressed } \\
\text { (only if SAR } \\
\text { present) }\end{array}$ \\
\hline $\begin{array}{l}\text { Approach to biodiversity } \\
\text { impacts }\end{array}$ & preventative & preventative & preventative & $\begin{array}{l}\text { avoidance, } \\
\text { mitigation, or } \\
\text { compensation }\end{array}$ & $\begin{array}{l}\text { avoidance, } \\
\text { mitigation, or } \\
\text { compensation }\end{array}$ & $\begin{array}{l}\text { Mitigation or } \\
\text { compensation }\end{array}$ \\
\hline Guidance and resources & Yes & Yes & Yes & Yes & Yes & Yes \\
\hline \multicolumn{7}{|c|}{$\begin{array}{l}\text { Does the policy integrate OBS Target \#12 \& \#13 (policies and plans include/protect natural heritage systems and 'well connected } \\
\text { networks')? }\end{array}$} \\
\hline $\begin{array}{l}\text { Connectivity } \\
\text { commitment/requirements }\end{array}$ & $\begin{array}{l}\text { yes, identification } \\
\text { necessary }\end{array}$ & $\begin{array}{l}\text { yes, protection } \\
\text { necessary }\end{array}$ & $\begin{array}{l}\text { yes, protection } \\
\text { necessary }\end{array}$ & no & no & $\begin{array}{l}\text { uncertain } \\
\text { (identified as a } \\
\text { routine } \\
\text { condition for } \\
\text { some species } \\
\text { at risk) }\end{array}$ \\
\hline Wildlife crossing structures & $\begin{array}{l}\text { specifically } \\
\text { mentioned in } \\
\text { guidance }\end{array}$ & Not mentioned & $\begin{array}{l}\text { Specifically } \\
\text { mentioned in } \\
\text { guidance (for } \\
\text { ORM) }\end{array}$ & unknown & $\begin{array}{l}\text { specifically } \\
\text { mentioned in } \\
\text { guidance }\end{array}$ & $\begin{array}{l}\text { specifically } \\
\text { mentioned in } \\
\text { guidance }\end{array}$ \\
\hline \multicolumn{7}{|c|}{ Has the policy helped create wildlife crossing structures? } \\
\hline Wildlife crossing in action & $\begin{array}{l}\text { yes (indirect and } \\
\text { select cases) }\end{array}$ & unknown & unknown & yes (direct) & yes (direct) & yes (direct) \\
\hline External barriers & \begin{tabular}{|l|} 
Yes (e.g. \\
financial, \\
community \\
\end{tabular} & unknown & unknown & $\begin{array}{l}\text { Yes (e.g. data } \\
\text { gaps and } \\
\text { financial cost of }\end{array}$ & $\begin{array}{l}\text { Yes (e.g. data } \\
\text { gaps and } \\
\text { financial cost }\end{array}$ & $\begin{array}{l}\text { Yes (e.g. data } \\
\text { gaps) }\end{array}$ \\
\hline
\end{tabular}




\begin{tabular}{|c|c|c|c|c|c|c|}
\hline & $\begin{array}{l}\text { support } \\
\text { necessary) }\end{array}$ & & & $\begin{array}{l}\text { wildlife crossing } \\
\text { structure) }\end{array}$ & $\begin{array}{l}\text { of wildlife } \\
\text { crossing } \\
\text { structure) }\end{array}$ & \\
\hline Policy barriers & $\begin{array}{l}\text { Yes (EA process } \\
\text { and land use } \\
\text { planning } \\
\text { disconnected) }\end{array}$ & $\begin{array}{l}\text { Yes (EA process } \\
\text { and land use } \\
\text { planning } \\
\text { disconnected) }\end{array}$ & $\begin{array}{l}\text { Yes (EA process } \\
\text { and land use } \\
\text { planning } \\
\text { disconnected) }\end{array}$ & $\begin{array}{l}\text { Yes (e.g. land } \\
\text { ownership } \\
\text { issues beyond } \\
\text { right-of-way) }\end{array}$ & $\begin{array}{l}\text { Yes (e.g. land } \\
\text { ownership } \\
\text { issues beyond } \\
\text { right-of-way) }\end{array}$ & $\begin{array}{l}\text { Yes (e.g. } \\
\text { designed for } \\
\text { mitigation, can } \\
\text { create hurdle } \\
\text { for } \\
\text { stewardship } \\
\text { work) }\end{array}$ \\
\hline Monitoring & Not required & Not required & Not required & $\begin{array}{l}\text { Yes (during } \\
\text { construction) }\end{array}$ & $\begin{array}{l}\text { Yes (scope } \\
\text { unknown) }\end{array}$ & $\begin{array}{l}\text { Yes (short term } \\
\text { required) }\end{array}$ \\
\hline
\end{tabular}




\subsection{Policy evaluation: assessment of relative strengths and weaknesses}

The six policies evaluated all have very different frameworks for implementation and all address both roads and biodiversity values in different ways. This is a product of their ranges in approach, application and implementation. Each policy received qualitative scores across the range created and as no weights were assigned to each criteria, examination of "Table \#13: Scoring policy effectiveness" was conducted by identifying relative strengths and weaknesses.

\section{Group 1: How does the policy work?/ When is the policy applied?}

\section{Strengths}

The land use planning polices were all evaluated to be strong in their approach to enable a landscapescale in decision-making. Through the development of regional and Official Plans, these policies all have the potential to integrate a framework that is most suited to integrating a systems perspective at a landscape-scale. The PPS sets the minimum standards that Official Plans "must be consistent with", which includes a requirement to protect significant natural areas and identify natural heritage systems in southern Ontario (MMAH, 2014). Official Plans then inform zoning by-laws and the requirements of EIS that are triggered through development applications in municipalities (City of Guelph, 2017). The Growth Plan, Greenbelt Plan, Oak Ridges Moraine Conservation Plan, and Niagara Escarpment Plan all build from the PPS and require additional landscape-scale planning requirements that prioritize natural systems protection (MMA, 2017a; MMA, 2017b).

The proactive nature of land use planning lends itself towards helping create a vision for a community, that can improve landscape connectivity considerations in road planning. Municipal implementation remains inconsistent in interpretation and implementation of some provincial plans. The Provincial land use plans reviewed offer a supportive framework to integrating landscape connectivity and biodiversity recovery into municipal Official Plans where political and public support exists.

\section{Weaknesses}

The approach of all the evaluated regulatory policies are project-based. The project-by-project nature of the two evaluated Class EA processes and the ESA can be identified as a relative weakness to addressing a complex issue like habitat fragmentation and biodiversity loss. The regulatory approach present in these three policies does not easily lend itself to a broader strategic approach to landscape connectivity, but rather evaluates each road project as it is brought forward. The policies are triggered by the introduction of a new road project, with avoidance or mitigation of impacts as the primary goals (MTO, 2017a; MNRF, 2018c). The process to plan for future road projects is primarily conducted through either a municipal Transportation Master Plans or Provincial Transportation Needs Assessments (Carruthers, 2018; Charleton, Andrew-McBride \& Hazell, 2018; Dagg-Foster, 2018; Nix \& Lefler, 2018;). The municipal Transportation Master Plan, while needing to remain consistent with municipal or regional land use plans was identified as largely disconnected from the Class EA for Municipal Infrastructure Projects and ESA processes, which are only triggered once a project is initiated. 


\section{Group 2: Does the policy integrate OBS Target \# 5 (policies integrate biodiversity values)?}

Strengths

All of the evaluated policies offered the opportunity for integration of biodiversity values into the development and decision-making processes.

As discussed above, land use policies through regional and Official Plan development offer the opportunity to promote a healthy natural environment, including ensuring biodiversity values are integrated into zoning by-laws and requirements of EISs (MMAH, 2018). This can help promote landscape connectivity in the planning and design of road projects throughout a given jurisdiction. The PPS and regional plans evaluated only represent a starting point for municipal planning (MMAH, 2018). The policies create a framework that would allow for this type of biodiversity-first approach to planning, however it is important to note that this may not be the direction of municipal Councils, and thus landscape connectivity is inconsistently applied across the province.

The regulatory polices reviewed all mandate the inclusion of environmental considerations at various stages of the planning and design of road projects. The Class EA for Provincial Transportation Facilities ensures that environmental impacts are considered in planning and design stages (MTO, 2017a). The Class EA for Provincial Transportation Facilities offers an opportunity for preventative action to be taken, with mitigation as a necessary outcome if the road project is determined to have a negative environmental impact to wildlife (MTO, 2017a).

\section{Weaknesses}

In terms of the integration of biodiversity values, the ESA was created to provide for the protection and recovery of Species at Risk (ESA, 2007). However, the prohibitions against damaging and destroying habitat of Species at Risk can be authorized if the requirements of a permit outlining actions to create an "overall benefit" to affected species in undertaken (MNRF, 2016). In practice the ESA acts as a regulatory requirement, with permitting identified as a component of the approvals process and not typically integrated in early planning stages.

\section{Group 3: Does the policy integrate OBS Target \#12 \& \#13 (policies and plans include/protect natural heritage systems and 'well connected networks')?}

Strengths

The Growth Plan and Greenbelt Plan, Oak Ridges Moraine Conservation Plan and Niagara Escarpment Plan were identified as most effective in terms of their requirement to protect connectivity through their planning process (MMA, 2017a; MMA, 2017b). These plans all have identified natural heritage systems that were created by the Province in order to identify core natural areas and corridors (MMA, 2017a; MMA, 2017b).

The ESA was also determined to effectively integrate elements that support the creation of well connected networks. When habitat or linkage areas within a species' identified range will be impacted by a road project, the ESA permit will likely require protection or maintenance of connectivity for the affected species (MNRF, 2016). This species-specific approach helps to promote connectivity, with a single plant or animal movement as the framework for creating systems protection. 


\section{Weaknesses}

Upon review of the two Class EA processes there did not appear to be specific mention of landscape connectivity (Ajax, 2007; MTO, 2000). This may be a product of the project-based evaluation process taken by each Class EA, as landscape considerations are most easily considered in processes that are not driven by project proponents. The requirement to address connectivity has been identified as an outcome of the EA process or subsequent permitting processes (MTO, 2000). In the case of the Class EA for Provincial Transportation Facilities, there are a number of environmental factors that are addressed which "may" include consideration for open-space linkages, depending on the depth of project assessment and local context (MTO, 2000). It is important to recognize that while, connectivity requirements are not identified specially within the two Class EA policy as requirements, supporting documents including Environmental Guide for Mitigating Road Impacts to Wildlife do specifically identify opportunities and guidelines to help bring wildlife crossing structures to fruition (MTO, 2017a).

\section{Group 4: Has the policy helped create wildlife crossing structures? Strengths}

The regulatory policies evaluated have all directly led to the creation of wildlife crossing structures (Carruthers, 2018; Charleton, Andrew-McBride \& Hazell, 2018; Crowley, 2018; Dagg-Foster, 2018; Gunson, 2018; Nix \& Lefler, 2018). The creation of these elements of wildlife connectivity have been a necessary element of meeting the conditions of both the Provincial and Municipal Class EA as well as receiving ESA permits (Carruthers, 2018; Charleton, Andrew-McBride \& Hazell, 2018; Crowley, 2018; Dagg-Foster, 2018; Gunson, 2018; Nix \& Lefler, 2018). These wildlife crossing structures have been installed across the province on both provincial or municipal roads to improve landscape connectivity and promote biodiversity recovery around roads.

\section{Weaknesses}

The land use planning process, due to its nature of developing overarching policy has not directly mandated the creation of wildlife crossing structures. The implementation of these land use plans are filtered down through the Official Plan, zoning by-laws and EISs, which is where wildlife crossing structures may be required as an element of new municipal road projects. Policies within land use plans are also considered through the Class EA processed (MTO, 2000).

There were examples identified where Official Plan policies that promoted landscape connectivity have led to the creation of wildlife crossing structures, but these do not appear to be the norm (Nix \& Lefler, 2018). Through the practitioner interviews that were completed and secondary research it was unclear if the Growth Plan or Greenbelt Plan, Oak Ridges Moraine Conservation Plan and Niagara Escarpment Plan have led to the implementation of wildlife crossing structures.

\subsection{Limitations of study}

This MRP offers an examination and comparison of six policies as they relate to improving landscape connectivity around road projects. As noted in Patton et al., "most policy analysis are incomplete" for factors including timing and resources (2013). It was discussed early on that over 60 statutes, regulations and government policies are relevant to the planning, design and management of Ontario road projects (MTO, 2014). This analysis only reviews the most often cited policies identified through a 
process of expert practitioner interviews. This sample of policies could have been expanded, as well as the pool of practitioners had time and resources allowed.

A major assumption applied throughout this analysis is that wildlife crossing structures promotes landscape connectivity and biodiversity recovery. It was briefly discussed that wildlife crossing structures can be used as a proxy that indicates landscape connectivity around roads. This ignores the effectiveness of the individual projects that each policy may have helped create. Factors including crossing design standards, fencing, and other management areas were not considered in detail when evaluating the types of structures each policy may or may not be helping to create. This evaluation simply investigated whether or not the policy was employing the use of wildlife crossing structures as a method to reconnect landscapes. 


\subsection{Findings and emerging opportunities}

This evaluation offers the opportunity to compare six identified policies side-by-side in order to better understand their approaches and effectiveness in integrating biodiversity targets and implementing wildlife crossing structures.

Biodiversity values are being integrated into the evaluated policies to various degrees and with various levels of success in improving conditions for wildlife. Across southern Ontario and the GGH more attention is needed to bolster biodiversity values in all policies that guide road projects in order to adequately address ongoing biodiversity decline in the face of rapid urbanization.

\subsection{Findings and recommendations}

The assessment of policy strengths and weaknesses (outlined in section 4.6) have helped identify five key findings. These findings and associated recommendations (indicated in bold), if addressed could help to improve landscape connectivity around roads by building connections between policy frameworks, reducing barriers to implementation, and improving agency collaboration.

\section{Building Policy Connections}

1) Landscape connectivity and biodiversity recovery benefit from the broad-scale and proactive approach of land use planning. However, implementation of wildlife crossing structures infrequently results from land use planning tools alone. In land use planning, the 'rubber meets the road' in how the PPS and regional plans are applied by individual municipalities in Official Plans, zoning by-laws and EIS requirements. Within recent years an increased attention to Natural Heritage Systems planning has been seen through changes to the PPS (now requiring municipalities identify a Natural Heritage System across southern Ontario), and through the provincially-led identification of a Natural System across for the GGH (MMAH, 2014; MMA, 2017a). However, the identification of these natural heritage systems remains largely disconnected from the planning and design of roads and isn't consistently applied in municipal policy. Effective municipal implementation is required to ensure natural heritage systems identification and protection, results in improvements to landscape connectivity around roads. Policy updates and reform with biodiversity in mind offers an opportunity for effective implementation of biodiversity commitments.

Improvements are needed to ensure policies within individual Official Plans, zoning by-laws, and EISs specifically acknowledge landscape connectivity and wildlife crossing structures in the planning and design of roads.

2) Implementation of wildlife crossing structures has successfully occurred through application of the evaluated regulatory policies. Practitioners report that the two evaluated Class EA processes and the ESA, in their project-based approach, have resulted in the creation of wildlife crossing structures around roads that directly sever natural areas. Broader landscape-scale considerations are not typically examined through these regulatory policies. It was also found that the landscape-scale approach that is possible in provincial and municipal land use plans is best suited to identifying opportunities to improve landscape connectivity at a regional scale. 
Stronger consideration in the two Class EA process and the ESA for landscape-scale considerations could improve the conditions for local and regional biodiversity.

A stronger connection is required in policy language to bridge the gap between the two Class EA processes and the ESA, with municipal natural heritage system planning (in lieu of regional strategic EAs and cumulative effect assessments).

\section{Reducing Barriers}

3) It was identified by expert practitioners that implementation of wildlife crossing structures, while increasing over the last decade have not become part of a typical road project, especially at the municipal level. This appears to be the case due to barriers that were identified including costs of projects, feasibility of site conditions, incomplete data, or a lack of familiarity with wildlife crossing structures. Amongst the wildlife crossing structures that expert practitioners outlined, it was noted that many came about opportunistically or due to an influential champion. Finding \#5, below, notes the need for further collaboration amongst agencies. Beyond increased collaboration, a strong and specific policy mandate to integrate wildlife crossing structures would help to mainstream their usage in areas that overlap with natural heritage systems or areas of high biodiversity value occurs.

A review is needed of the evaluated policies with a goal to introduce new language that specifically guides the inclusion of wildlife crossing structures as a strategy to promote landscape connectivity as the norm when roads interrupt animal movement.

4) The implementation of wildlife crossing structures is largely occurring through regulatory requirements for species at risk or to protect public safety (through the Class EAs) as a result of a new road project or new development activity. These successful examples are coming to fruition in places where road projects are being planned or are underway. It was identified by practitioners that many barriers existed to implement wildlife crossing structures in areas where wildlife mortality or fragmentation is high, unless a new development was planned. Many sites across southern Ontario are known to be hot-spots for wildlife mortality and wildlife-vehicle collisions, however, mitigation measures currently rely on signage and public awareness (not added infrastructure). A major policy gap exists in creating wildlife crossing structures in areas of high wildlife mortality and no new project is planned.

New mechanisms, sources of funding, and policies should be identified to promote the creation of wildlife crossing structures (where feasible) to improve landscape connectivity in areas where no road projects are planned.

Improving Agency Collaboration

5) Promoting landscape connectivity and addressing biodiversity decline is a complex problem, with overlapping responsibilities for implementation and a wide range in applicable polices. Problems of this nature benefit from broad collaboration amongst policy makers and implementors at all levels of government and between agencies/ministries. There often appears to be a disconnection between agencies and departments concerned with biodiversity and 
those planning and designing road projects (Yuan, 2014). This disconnect is especially prevalent at the municipal level (formal structures for inter-ministerial collaboration around biodiversity do exist within the Provincial government). Gaps often exist in knowledge and communications around capital investments and roads projects at the municipal level.

\section{Opportunities should be explored to establish formal collaborations amongst government agencies and departments involved in the delivery of road projects and those tasked with biodiversity conservation, to create positive outcomes for landscape connectivity.}

\subsection{Emerging opportunity: areas for action}

This evaluation demonstrates that identified Ontario policies have had mixed results in their effectiveness to promote landscape connectivity. More action is needed to improve the effectiveness of these policies and to fill gaps that may be preventing more widespread implementation of wildlife crossing structures.

To build off this evaluation a co-laboratory approach could help to address research questions and areas for inquiry that have emerged through this MRP. A co-laboratory process employs design-thinking models, that employ a collaborative and interdisciplinary approach to problem solving, to facilitate a conversation amongst a diverse range of expert practitioners (Aird, 2017). In this case, practitioners from agencies involved in biodiversity recovery, road projects and implementation of wildlife crossing structures could be brought together to work through the following identified areas for future research:

\section{Building Policy Connections}

- Expanding the scope of the two evaluated Class EAs to better aligning with municipal or regional land use plans.

o Key research questions:

- Are there areas for improvement where the Class EA for Provincial Transportation Facilities or Municipal Infrastructure Projects can better integrate municipal land use planning?

- How can the EA process better integrate broad-scale landscape considerations and cumulative impacts of habitat fragmentation?

\section{Reducing Barriers}

- How to effectively use municipal land use planning tools and policies to integrate wildlife crossing structures.

o Key research questions:

- What can be learned from municipalities that have successfully integrated wildlife crossing structures through use of planning tools (Official Plans, zoning by-laws and EIA requirements)?

- What policies need to be adapted to ensure wildlife crossing structures are part of road projects that intersect an identified natural heritage system?

Improving Agency Collaboration

- Improving interagency and intergovernmental collaboration to improve landscape connectivity

0 Key research question 
- What mechanisms can be used to improve communication and collaboration of the wide range of agencies that are working on road projects and recovering biodiversity?

\subsection{Emerging opportunity: regional connectivity and achieving Canada's Target 1}

The value of landscape connectivity and landscape resilience is being increasingly recognized in the fields of conservation, planning and policy-making. Attention at the national level in Canada may create new opportunities to promote the integration of wildlife crossing structures to improve connectivity around provincial and municipal roads.

The biodiversity targets and commitments that have flowed from the Aichi Targets have taken slightly different interpretations at both the national and provincial level (Figure 10: International, national and provincial targets relevant to landscape connectivity and road projects). At the national level, Canada's Target \#1 closely resembles Aichi Target \#11 and OBS Target \#5 with a focus to increase protected areas in a network that places focus on landscape connectivity:

Canada's Target \#1: "By 2020, at least $17 \%$ of terrestrial areas ... of Canada are conserved through networks of protected areas and other effective area-based measures" (ECCC, 2016).

Canada currently ranks last among G7 nations in percentage of land protected for nature, with only $10 \%$ of the country in a formal protected area (Figure 14) (CPAWS, 2017). With little time remaining before the approaching target deadlines, urgent action is required to engage all levels of government to increase protected areas, with a focus to promote landscape connectivity and biodiversity recovery.

Figure 14: Comparison of protected area coverage in G7 countries (CPAWS, 2017)

Figure 1. Comparison of protected area coverage in G7 countries

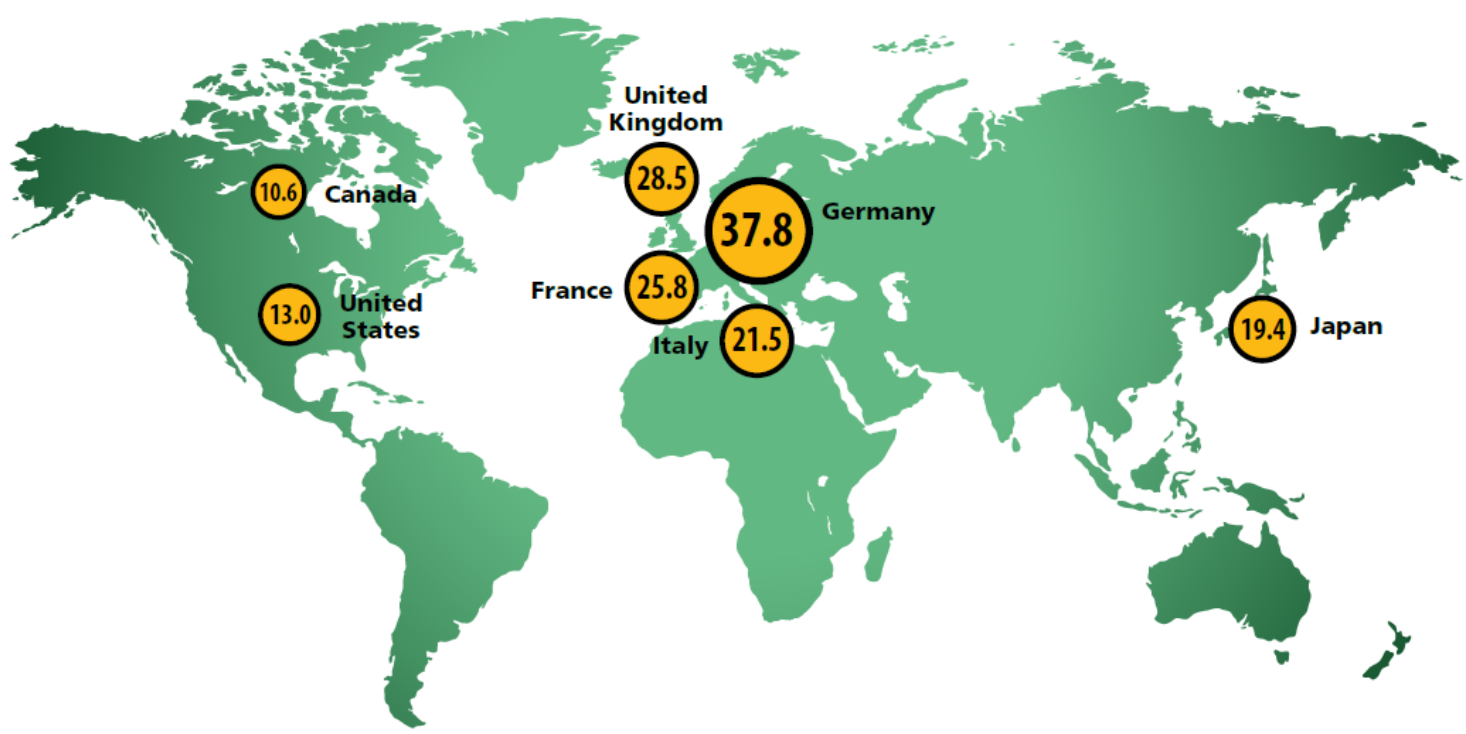


Along with provincial and territorial partners, the Federal government launched The Pathway to Canada Target 1 group which has begun to create momentum to achieving this target (NAP, 2018). The National Advisory Panel has developed recommendations and Discussion Papers to move this initiative forward, including a focus on promoting landscape connectivity.

The National Advisory Panel in their 2018 report Canada's Conservation Vision, specifically identified the need to integrate "better consideration of connectivity in planning for and managing roads... to mitigate their impacts and maintain or restore movement and flow of species" (NAP, 2018). Within the NAP's Discussion Paper on Landscape Connectivity and Integration in Protected Areas and Conservation Areas, authors identify the need to leverage the strength of land use planners to help sustain regional connectivity, with local implementation (Deshaies, 2017).

This presents an important opportunity in Ontario. Many municipal and regional plans identify natural heritage systems, which may offer an opportunity to increase the province's share of connected and protected areas. The natural heritage systems of the Greenbelt, ORM, NE and Growth Plan, along with established municipal systems would require additional policy mechanisms to qualify as protected areas or 'other effective area-based conservation measures' (Gray et al., 2009). Pointed policy updates that include provisions for their long-term protection and a primary policy objective of nature conservation would move these areas closer to contributing to national and provincial protected areas targets (SBSTTA, 2018).

The policy framework evaluated in this MRP have important implications for the implementation of Canada's Target \#1 and OBS Target \#13 as provincial and municipal roads represent important pinch points that can disrupt connectivity between protected areas and other effective area-based conservation measures. To achieve national, provincial, regional or local connectivity targets that demand landscape connectivity, the building of strategically placed wildlife crossing structures must be included.

To help achieve Canada's Target \#1 and the OBS's Target \#13, policies are needed to encourage collaboration amongst the various levels of government to increase the use of wildlife crossing structures. Policies that integrate broader collaboration could promote inter and intra agency coordination as road projects and biodiversity considerations are not the mandates of a single agency.

\subsection{Approaching 2020 at the intersection of biodiversity and roads}

Reversing the decline of wildlife loss and biodiversity was identified by Ontario's Environmental Commission as "one of the greatest environmental challenges of our time" (ECO, 2015). Addressing the negative impacts of roads to biodiversity will require widespread action focused on improving landscape connectivity. In rapidly urbanizing areas like southern Ontario and the GGH, biodiversity recovery will require continued integration of biodiversity values into road projects through the implementation of wildlife crossing structures. This evaluation has shown that the existing policy framework has some strengths that can promote landscape connectivity and weakness that have hindered the recovery of wild species.

With major changes to the responsibilities of ministries resulting from the Spring 2018 Provincial election much uncertainty exists in how key policies will be implemented (i.e. shifting of the parks and 
conservation portfolios from the Ministry of Natural Resources and Forestry to the Ministry of Environment, Parks and Conservation). However, new opportunities may also emerge to enable new areas for collaboration amongst ministries and agencies that may improve implementation of existing policies to improve landscape connectivity.

The land use planning structure in this region has increased considerations for landscape connectivity through the PPS, Growth Plan, Greenbelt Plan, Oak Ridges Moraine Conservation Plan, and Niagara Escarpment Plan. These plans have improved protection for key natural areas and all consider the importance of connectivity. However, the systems-level protection for natural heritage, and road and infrastructure polices remain largely disconnected. Further integration between land use planning tools and regulatory tools is needed and could help lead to widespread uptake in wildlife crossing structures.

In Ontario the Ontario Biodiversity Strategy represents an important framework for action that aligns provincial and municipal activity with broader national and global targets. With the target date of 2020 fast approaching, attention is needed in order to ensure all road projects effectively integrate wildlife crossing structures. Urgent and coordinated action is needed, to increase policy effectiveness in order to improve landscape connectivity across a heavily urban environment with a vast network of roads.

Effective policy can help to ensure that as the region continues to grow biodiversity values are effectively integrated into decision making.

Figure 15: Eastern redback salamander far from a road in the Happy Valley Forest, King, Ontario (Wise, 2016)

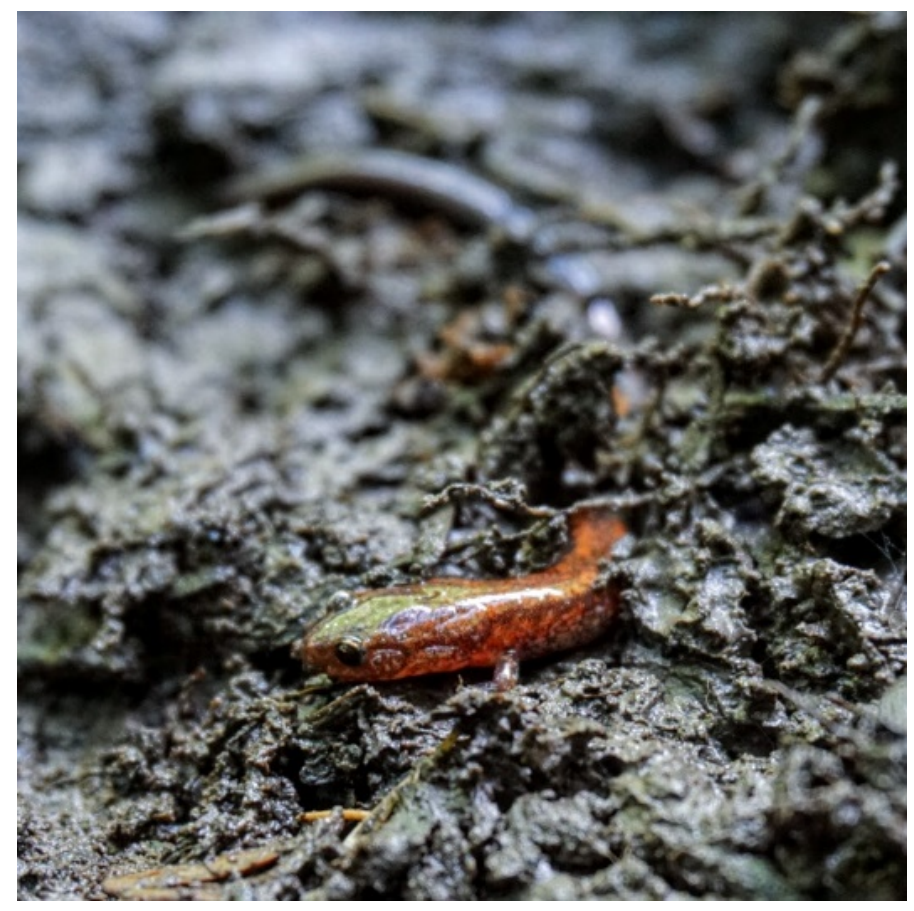




\section{Appendix}

Appendix A: Summary of Social Sciences and Humanities Research Council of Canada (SSHRC), held by Prof. Nina-Marie Lister through the Ecological Design Lab at Ryerson University.

Safe Passage: Towards and Integrated Planning Approach for Landscape Connectivity

\section{Summary of Proposal}

Roads fragment landscapes, resulting in barriers to the safe movement of humans and animals. Canada's growing urban regions and road networks are associated with increasing wildlife-vehicle collisions and in the long term, landscape fragmentation can result in habitat degradation a decline in biodiversity.

There is strong evidence that wildlife crossing infrastructure can dramatically reduce the risk of collisions and mediate negative environmental impacts. Yet where the construction of wildlife crossing infrastructure has emerged, it has been slow, sparse and ad hoc. Solving these issues is not solely a technical or research challenge; it is about working collaboratively across disciplines and building political, economic, and cultural consensus. This partnership recognizes that there is an emerging public policy and infrastructural design imperative to find new and creative ways to (re)connect our landscapes in support of the safe passage of humans and animals. By engaging with these issues in a unique interdisciplinary and experiential learning format that links landscape design and road ecology with evidence-based policy and urban environmental planning, this partnership creates new opportunities for advanced research and civic engagement.

This three year project is aimed at the development of an integrated approach for the sustainable planning, design, and implementation of crossing infrastructure and improved landscape connectivity. Safe Passage: Towards an Integrated Planning Approach for Landscape Connectivity aims to: (re)connect landscapes for the safe passage of humans and wildlife; reach Canada's predominantly urban population by bringing landscape connectivity issues to the urban scale; and improve our contemporary relationship with wildlife in and around our cities through innovative planning and design. Specifically, it will create a dynamic working forum for the collaboration of university researchers, practitioners,

and community leaders for the shared goal of creating a policy and implementation framework for landscape connectivity. The partnership's collaborative approach culminates in the CoLaboratories--researched-based, collaborative studio workshops in which participants come together to apply, present and share emerging research in the design of new solutions for human and wildlife mobility across urbanizing landscapes. The partnership will develop and deliver tangible solutions to issues surrounding landscape fragmentation in two of Canada's rapidly urbanizing centres, Toronto and Edmonton.

This partnership is structured around a closely-linked working group comprised of academics from 4 universities (Ryerson University, University of Toronto, Royal Roads University and Montana State University) and partner organizations who contribute to the three phases of the project over three years. Community leaders in urban and landscape planning and conservation: Evergreen Brick Works, Toronto Zoo, Toronto \& Region Conservation Authority, City of Toronto, City of Edmonton, Miistakis Institute and ARC Solutions, have pledged to work alongside a group of professional planners, landscape architects, ecologists, and sustainability and policy experts to generate the material results of this partnership for public exhibition, policy stimulus, and civic dialogue. The project brings several benefits to Canada through engagement with one of our most pressing environmental concerns and by training highly qualified personnel in the inter-related disciplines of evidence-based policy creation, ecological design, and planning. More broadly it will provide Canadians with a timely opportunity to engage in complex socio-ecological issues and to re-imagine our collective relationship the shared landscapes we call home. 
Appendix B: Expert Practitioner Interview Guide

\section{Safe Passage: Towards an Integrated Planning Approach for Landscape Connectivity Planning and Design Professionals -- Practitioner Interview Script Updated May 4, 2018}

INTERVIEW

\section{PART ONE: POLICY \& PLANNING}

1. Are you aware of an existing plan or policy that aims to connect natural heritage / open spaces / green spaces (e.g. trails, parks, ravines etc.) in your town/city/region?

- Can you explain the scope or approach of these policies?

- What agency is charged with applying this policy?

- To your understanding, has this policy been successful in promoting landscape connectivity? What weaknesses exist? What could be improved?

- Is the development of a policy or plan that aims to connect such green spaces currently underway? 2. Is there any plan of policy in place that specifically mentions of promotes the creation of wildlife crossing infrastructure in your town/city/region?

3. Do you see any barriers to implementing wildlife crossing infrastructure or promoting landscape connectivity in your town/city/region?

- Are there policy gaps that limit the ability to reconnect landscape or build wildlife crossings?

- Are there policies with conflicting interests that limit the ability to reconnect landscapes around roads or build wildlife crossings?

- Are there other barriers (policies, inter/intra-agency issues) that you feel hinder the ability to build wildlife crossings? Are there positive policies or collaborations we should note?

4. Is there existing or planned infrastructure to facilitate wildlife (animal) movement throughout your town/city/region (e.g. passages, corridors, bridges, tunnels, culverts or other designed infrastructure)?

- Are there additional resources that we could access to learn more about these existing structures?

- Is there any agency that you know of that is tracking this type of infrastructure projects? 5. [Mostly just for government interviews] What systems for collaboration in decision-making internally are in place at your organization (with regards to the creation of wildlife crossings/landscape connectivity)?

- Are there formal or informal structures in place (both)? Are there internal policies that enable this type of collaboration?

- Are these structures effective in helping create wildlife crossings/landscape connectivity? Are there are they could be improved?

6. What systems for collaboration in decision-making between (and/or among) agencies are in place that you are aware or, or that your organization participated in (i.e. cross-agency collaborations)?

- Are there formal or informal structures in place (both)? Is there legislation or jurisdictional reasons for the collaboration?

- Are these structures effective in helping create wildlife crossings/landscape connectivity? Are there are they could be improved?

7. Are there other important policy or planning considerations we should be aware of in your jurisdiction that haven't been touched on?

\section{PART TWO: IMPLEMENTATION}

Q's on Road Infrastructure broadly:

8. What agencies/players are involved in the delivery of road infrastructure projects in your jurisdiction?

- At what stage in the procurement process is each agency involved?

9. Do you have a sense of what the existing procurement/project delivery process for road infrastructure projects in your town/city/region? (e.g. design-build, design-bid-build, public-private-partnership, CM/GC Construction Manager/General Contractor etc.)

- At what stage in the project procurement process are contractors engaged?

- How do ecological / landscape considerations become involved in the process?

- Do/When do landscape architectural sub-trades become involved? 
10. Do you have a sense of how are the costs of implementing new infrastructure estimated / evaluated?

- Are the life-cycle costs of delivering and maintaining infrastructure considered?

- What is the life-cycle costing method used?

- Are wildlife/biodiversity values integrated in this cost estimate? Are Wildlife-vehicle incidents and insurance considerations involved?

$Q$ 's on Wildlife crossing infrastructure:

11. What agencies are involved in the delivery of wildlife crossing infrastructure projects in your jurisdiction?

- At what stages in the procurement process in each agency involved?

12. If a wildlife crossing project exists that you have been involved with, can you quickly walk us through the implementation process that made that possible?

- Why did this project work? What barriers exists that don't allow this to become the implementation norm?

13. What are the existing road/highway design standards used to determine overpass and underpass width, span and load?

- Are existing non-vehicular overpass/underpass infrastructure being monitored for wildlife? (e.g. with IR/MS cameras, track pads, electronic warning signage etc)

14. Are there other important implementation considerations we should be aware of in your jurisdiction that haven't been touched on?

PART THREE: DATA

15. Are you aware of the primary sources of data that are used to inform the transportation planning process (e.g. siting, design, etc...) in your town/city/region?

- Is wildlife movement considered? Is any data to consider this used in policy or implementation process?

- Are data regarding wildlife road mortality collected?

- Are data for wildlife-vehicle collisions (and associated zones) collected?

- Are existing WVC "hotspots" identified?

- Are there warning systems in place (e.g. standard zone signage; movement-triggered flashing signes / electronic warning signage etc.)

16. Is existing road crossing infrastructure monitored for wildlife use (e.g. with IR/MS cameras, track pads etc)? Please explain

- Any success stories that can be shared?

17. Are data measuring biodiversity and ecosystem integrity available within your jurisdiction? If so, what are these, and who develops them?

- Are there measures that evaluate biodiversity and ecosystem integrity that would be relevant to this research?

18. Is information regarding planned local road improvements available to agencies outside the transportation / engineering planning department (or the collecting authority)?

- How is this information disseminated or shared?

19. Are there other important data considerations we should be aware of in your jurisdiction that haven't been touched on?

Wrap Up

20. Are there any last details to add? Anything we have missed or that you want to underscore/clarify from earlier responses?

21. We are hoping to expand our interview sample and are hoping you can suggest five key experts in jurisdictions across Canada that you think we should make sure to interview. Can you please provide us with their contact information? 
Appendix C: Summary of relevant policies identified through expert practitioner interviews

Group 1: Land use policies
\begin{tabular}{|l|l|}
\hline Provincial Policy Statement, 2014 \\
\hline Objective/vision & $\begin{array}{l}\text { "The long-term prosperity and social well-bring of Ontario depends upon planning for } \\
\text { strong, sustainable and resilient communities for people of all ages, a clean and } \\
\text { healthy environment, and a strong and competitive economy" }\end{array}$ \\
\hline $\begin{array}{l}\text { Relevance to road } \\
\text { projects }\end{array}$ & facilitates/guides the planning of transportation systems and infrastructure corridors \\
\hline $\begin{array}{l}\text { Relevance to landscape } \\
\text { connectivity and } \\
\text { biodiversity protection }\end{array}$ & $\begin{array}{l}\text { promotes the protection of natural heritage systems and protects significant natural } \\
\text { features }\end{array}$ \\
\hline Legislated authority & Issued under the Planning Act, 1990 \\
\hline Policy scope & $\begin{array}{l}\text { - sets the policy foundation for regulating the development and use of land. All } \\
\text { planning matters "shall be consistent with" this policy statement. } \\
\text { - guides the development of a municipal Official Plan and Environmental Impacts } \\
\text { Statement process }\end{array}$ \\
\hline Agency in charge & Ontario Ministry of Municipal Affairs and Housing \\
\hline Key facts & $\begin{array}{l}\text { The PPS provides policy direction on matters of provincial interest related to land use } \\
\text { planning and development. }\end{array}$ \\
\hline Milestones & Updated in 2014 \\
\hline Geographic Scope & Ontario-wide, with policy differentiation based on eco-zone \\
\hline $\begin{array}{l}\text { Associated guidance } \\
\text { documents }\end{array}$ & $\begin{array}{l}\text { - Natural Heritage Reference Manual (MNRF, 2010) } \\
\text { - Municipal Official Plans and associated municipal guidance including: Natural } \\
\text { Heritage Systems, Environmental Impact Statements (depending on municipal } \\
\text { implementation) }\end{array}$ \\
\hline Source(s) & MMAH, 2014; MNRF, 2010 \\
\hline
\end{tabular}

\begin{tabular}{|l|l|}
\hline Growth Plan for the Greater Golden Horseshoe, 2017 \\
\hline Objective/vision & $\begin{array}{l}\text { "the Greater Golden Horseshoe will continue to be a great place to live. Its } \\
\text { communities will be supported by a strong economy, a clean and healthy } \\
\text { environment, and social equity" }\end{array}$ \\
\hline $\begin{array}{l}\text { Relevance to road } \\
\text { projects }\end{array}$ & $\begin{array}{l}\text { Aims to coordinate transportation system planning, land use planning and } \\
\text { transportation investment }\end{array}$ \\
\hline $\begin{array}{l}\text { Relevance to landscape } \\
\text { connectivity and } \\
\text { biodiversity protection }\end{array}$ & $\begin{array}{l}\text { Requires municipalities to incorporate a provincially identified Natural Heritage } \\
\text { System as an overlay in official plans and apply policies to maintain, restore and } \\
\text { enhance the diversity and connectivity of the system }\end{array}$ \\
\hline Legislated authority & Prepared and approved under the Places to Grow Act, 2005 \\
\hline Policy scope & $\begin{array}{l}\text { Regional growth plan that guides government investment and land use planning } \\
\text { policies in the GGH }\end{array}$ \\
\hline Agency in charge & Ministry of Municipal Affairs and Housing \\
\hline Key facts & $\begin{array}{l}\text { The Growth Plan informs decision-making regarding growth management and } \\
\text { environmental protection in the GGH. This plan builds on the policy foundation of the } \\
\text { PPS and provides more specific land use planning policies }\end{array}$ \\
\hline Milestones & Updated in 2017 \\
\hline Geographic Scope & Greater Golden Horseshoe region \\
\hline $\begin{array}{l}\text { Associated guidance } \\
\text { documents }\end{array}$ & $\begin{array}{l}\text { The Regional Natural Heritage System for the Growth Plan for the Greater Golden } \\
\text { Horseshoe: Technical Report on Criteria, Rationale and Methods (MNRF, 2018) }\end{array}$ \\
\hline Source(s) & MMA, 2017a; MNRF, 2018 \\
\hline
\end{tabular}

Greenbelt Plan, Oak Ridges Moraine Conservation Plan (ORMCP), Niagara Escarpment Plan (NEP), 2017 


\begin{tabular}{|l|l|}
\hline Objective/vision & $\begin{array}{l}\text { Greenbelt Plan: "The Greenbelt is a broad band of permanently protected land which } \\
\text {... gives permanent protection to the natural heritage and water resource systems } \\
\text { that sustain ecological and human health and that form the environmental framework } \\
\text { around which major urbanization in south-central Ontario will be organized" }\end{array}$ \\
\hline $\begin{array}{l}\text { Relevance to road } \\
\text { projects }\end{array}$ & $\begin{array}{l}\text { The Greenbelt Plan, together with the ORMCP and NEP identify where urbanization } \\
\text { should not occur. The Greenbelt Plan does not offer specific policy with respect to } \\
\text { planning and siting road networks. }\end{array}$ \\
\hline $\begin{array}{l}\text { Relevance to landscape } \\
\text { connectivity and } \\
\text { biodiversity protection }\end{array}$ & $\begin{array}{l}\text { The three plans identify and include policies to protect a natural heritage system } \\
\text { (including ORM Core and Linkage areas and NE protected areas). These Natural } \\
\text { System policies acknowledge the importance of large-scale landscape connectivity to } \\
\text { support biodiversity movement. }\end{array}$ \\
\hline Legislated authority & $\begin{array}{l}\text { Greenbelt Act, 2005; Oak Ridges Moraine Conservation Act, 2001; Niagara } \\
\text { Escarpment Planning and Development Act }\end{array}$ \\
\hline Policy scope & $\begin{array}{l}\text { Regional plans that identify specific policy requirements within an area identified to } \\
\text { prioritize agricultural and natural heritage over development. }\end{array}$ \\
\hline Agency in charge & $\begin{array}{l}\text { Ministry of Municipal Affairs and Housing (Greenbelt, ORM); Ministry of Natural } \\
\text { Resources and Forestry and Niagara Escarpment Commission (Niagara Escarpment) }\end{array}$ \\
\hline Key facts & Updated in 2017 \\
\hline Milestones & Three identified regions/geologic formations within the GGH \\
\hline Geographic Scope & $\begin{array}{l}\text { - Technical Definitions and Criteria for Key Natural Heritage Features in the Natural } \\
\text { Heritage System of the Protected Countryside Area (MNR, 2012) } \\
\text { - ORMCP Technical Paper Series (includes 17 documents to help apply natural } \\
\text { heritage polices) }\end{array}$ \\
\hline $\begin{array}{l}\text { Associated guidance } \\
\text { documents }\end{array}$ & MMA 2017b; MMA 2017c; NEC, 2017; MNR, 2012 \\
\hline Source(s) &
\end{tabular}

Group 2: Regulatory policies

\begin{tabular}{|l|l|}
\hline Class Environmental Assessment for Provincial Transportation Facilities \\
\hline Objective/vision & $\begin{array}{l}\text { "to provide a safe and effective transportation system while avoiding or minimizing } \\
\text { negative environmental effects" }\end{array}$ \\
\hline $\begin{array}{l}\text { Relevance to road } \\
\text { projects }\end{array}$ & guides the planning of all provincial roads projects in Ontario \\
\hline $\begin{array}{l}\text { Relevance to landscape } \\
\text { connectivity and } \\
\text { biodiversity protection }\end{array}$ & $\begin{array}{l}\text { outlines the requirements of MTO to conduct studies and/or projects with an } \\
\text { inherent approach of avoiding or minimizing overall environmental impacts; identify } \\
\text { existing environmental conditions and potential impacts of projects; address the } \\
\text { MTO's Statement of Environmental Values; balance environmental protection with } \\
\text { transportation engineering considerations during each stage of the process }\end{array}$ \\
\hline Legislated authority & Environmental Assessment Act, 1990 \\
\hline Policy scope & $\begin{array}{l}\text { The class EA defined what must be achieved in the planning, preliminary design, detail } \\
\text { design and construction of provincial road projects }\end{array}$ \\
\hline Agency in charge & $\begin{array}{l}\text { - Ministry of Transportation (owner of Class EA for Provincial Transportation Facilities) } \\
\text { - Ministry of Environment Conservation and Parks (authority over the EA Act) }\end{array}$ \\
\hline Key facts & $\begin{array}{l}\text { A Class EA is intended to generate significant efficiencies and cost-savings to the } \\
\text { proponent, delivery partners, agencies and the public by following a pre-approved, } \\
\text { predictable EA process }\end{array}$ \\
\hline Milestones & Updated in 2000. MTO has used a Class EA since 1979, this is the fourth generation \\
\hline Geographic Scope & Ontario-wide \\
\hline $\begin{array}{l}\text { Associated guidance } \\
\text { documents }\end{array}$ & $\begin{array}{l}\text { - Environmental Guide for Mitigating Road Impacts to Wildlife: Part of the } \\
\text { Environmental Standards and Practices (MTO, 2017a) }\end{array}$ \\
\hline
\end{tabular}




\begin{tabular}{|l|l|}
\hline & $\begin{array}{l}\text { - Environmental Protection Requirements for Transportation Planning and Highway } \\
\text { Design, Construction, Operation and Maintenance (MTO, 2014) }\end{array}$ \\
\hline Source(s) & MTO, 2000; MTO, 2017a; MTO, 2014 \\
\hline
\end{tabular}

\begin{tabular}{|c|c|}
\hline \multicolumn{2}{|c|}{ Municipal Engineers Association's Class EA } \\
\hline Objective/vision & $\begin{array}{l}\text { Municipal Class EA: a document approved by the Minister of the Environment that } \\
\text { sets out a self-assessment process for how municipalities and private sector } \\
\text { developers plan municipal infrastructure projects. } \\
\text { Ontario EA Act: to provide for the betterment of the people of the whole or any part } \\
\text { of Ontario by providing for the protection, conservation and wise management in } \\
\text { Ontario of the Environment }\end{array}$ \\
\hline $\begin{array}{l}\text { Relevance to road } \\
\text { projects }\end{array}$ & Municipal Class EA applies to municipal infrastructure projects including roads. \\
\hline $\begin{array}{l}\text { Relevance to landscape } \\
\text { connectivity and } \\
\text { biodiversity protection }\end{array}$ & $\begin{array}{l}\text { Considers a reasonable range of alternative, including a range of alternatives (both } \\
\text { functional alternatives and alternative methods) as projects are proposed and are } \\
\text { identified to have an impact of the environment. }\end{array}$ \\
\hline Legislated authority & Environmental Assessment Act, 1990 \\
\hline Policy scope & $\begin{array}{l}\text { Project-by-project. This Class EA establishes a planning and approval process for a } \\
\text { variety of municipal infrastructure projects including roads, water and wastewater } \\
\text { projects }\end{array}$ \\
\hline Agency in charge & Municipal Engineers Association and Ministry of Environment Conservation and Parks \\
\hline Key facts & $\begin{array}{l}\text { Municipalities undertake hundreds of projects. The Class EA process provides } \\
\text { decision-making framework that enables the requirements of the EA Act to be met in } \\
\text { an effective manner. The main expected differences across Ontario municipalities } \\
\text { include project-specific problems, opportunities, environmental and community } \\
\text { issues. }\end{array}$ \\
\hline Milestones & Updated 2015. \\
\hline Geographic Scope & Projects occurring in Ontario \\
\hline $\begin{array}{l}\text { Associated guidance } \\
\text { documents }\end{array}$ & $\begin{array}{l}\text { - Municipal Engineering Association web site hosts resources and implementation } \\
\text { tools }\end{array}$ \\
\hline Source(s) & MEA, 2015; MECP, 2018; Ajax, 2007 \\
\hline
\end{tabular}

\begin{tabular}{|l|l|}
\hline Ontario Endangered Species Act, 2007 \\
\hline Objective/vision & $\begin{array}{l}\text { "To identify species at risk based on the best available scientific information, including } \\
\text { information obtained from community knowledge and aboriginal traditional } \\
\text { knowledge. } \\
\text { To protect species that are at risk and their habitats, and to promote the recovery of } \\
\text { species that are at risk. } \\
\text { To promote stewardship activities to assist in the protection and recovery of species } \\
\text { that are at risk." }\end{array}$ \\
\hline $\begin{array}{l}\text { Relevance to road } \\
\text { projects }\end{array}$ & $\begin{array}{l}\text { The Act prohibits the harm, harassment, or killing of endangered or threatened } \\
\text { species at risk, and the damage and destruction of Endangered or Threatened Species } \\
\text { habitat in Ontario, unless an authorization is obtained. This would apply to any road } \\
\text { project that would impact Species at Risk habitat }\end{array}$ \\
\hline $\begin{array}{l}\text { Relevance to landscape } \\
\text { connectivity and } \\
\text { biodiversity protection }\end{array}$ & $\begin{array}{l}\text { The Act protects species and all the habitat they rely on or use, including movement } \\
\text { corridors and seasonal habitat. }\end{array}$ \\
\hline Legislated authority & Endangered Species Act, 2007 \\
\hline Policy scope & Permits are issued on a project-by-project basis \\
\hline Agency in charge & Ministry of Environment, Conservation and Parks (as of June, 2018) \\
\hline Key facts & \\
\hline
\end{tabular}




\begin{tabular}{|l|l|}
\hline Milestones & $\begin{array}{l}\text { - Policy passed in 2007 } \\
\text { - July } 2013 \text { regulatory amendments introduced a "rules in regulation" approach } \\
\text { creating additional exemptions to requirements for permits/agreements through } \\
\text { Ontario Regulation 242/08 }\end{array}$ \\
\hline Geographic Scope & Province-wide \\
\hline $\begin{array}{l}\text { Associated guidance } \\
\text { documents }\end{array}$ & $\begin{array}{l}\text { - Best Management Practices for Mitigating the Effects of Roads on Amphibians and } \\
\text { Reptile Species at Risk in Ontario (Gunson, 2016) } \\
\text {-MTO Best Management Practices for Species at Risk Protection During Maintenance } \\
\text { Activities (MTO, 2017b) } \\
\text { - A Guide to Road Ecology (OREG, 2010) }\end{array}$ \\
\hline Source(s) & MNRF, 2018a; ECO, 2013 \\
\hline
\end{tabular}




\section{References}

Aird, B. (2017). CoLaboratory Methodology \& Context. Unpublished manuscript, School of Urban and Regional Planning, Ryerson University, Toronto, Canada.

Ajax, City of. (2007). Class Environmental Assessment Process Guide. City of Ajax. Retrieved from: https://www.ajax.ca/en/doingbusinessinajax/resources/ClassEnvironmentalAssessmentProcessGuide.p df.

ARC (n.d.). ARC Special Publication: Innovative Strategies to reduce the cost of effective wildlife overpasses. Accessed from: https://arc-solutions.org/wp-content/uploads/2017/04/ARC-Special-PubDesign-Parameters.pdf.

ARC Solutions. (2018). How can design save wildlife and wild places? Retrieved from https://arcsolutions.org/what-is-arc/.

Bardach, Eugene. (2012). A Practical Guide for Policy Analysis: The Eightfold Path of More Effective Problem Solving ( $4^{\text {th }}$ Edition). Thousand Oaks, California: CQ Press.

Beckmann, J.P.; and Hilty, J.A. (2014). Connecting Wildlife Populations in Fractured Landscapes. In J.P. Beckmann el al. (Eds). Safe Passages: Highways, Wildlife, and Habitat Connectivity. Island Press: ProQuest Ebook Central Retrieved from: https://ebookcentral-proquestcom.ezproxy.lib.ryerson.ca/lib/ryerson/detail.action?doclD=3317504.

Benítez-López, A., Alkemade, R., \& Verweij, P. A. (2010). The impacts of roads and other infrastructure on mammal and bird populations: A meta-analysis. Biological Conservation, 143(6), 1307-1316.

Brocki, M \& Lister, N.M. (2014). Embracing Complexity: Ecological Designs for Living Landscapes. Oz: Vol. 36, Article 7.

Burch, P., \& Heinrich, C.J. (2016). Mixed Methods for Policy Research and Program Evaluation. London, UK: SAGE Publications, Inc.

Canadian Parks and Wilderness Society (CPAWS). (2017). From Laggard to Leader? Canada's Renewed Focus on Protecting Nature Could Deliver Results. Retrieved from: http://cpaws.org/uploads/CPAWSParks-Report-2017.pdf.

Communities and Local Government UK. (2009). Multi Criteria Analysis: A Manual. Department of Communities and Local Government: London, UK.

Coristine, L.E., Jacob, A.L., Schuster, R., Otto, S. P., Baron, N. E., Bennet, N. J., Bittick, S.J., et al.. (2018). Informing Canada's commitment to biodiversity conservation: A science-based framework to help guide protected areas designation through Target 1 and beyond. FACETS 3, 531- 562.

Costanza, R., d'Arge, R., de Groot, R., Farber, S., Grasso, M., Hannon, B., Limburg, K., ... van den Belt, M. (1997). The value of the world's ecosystem services and natural capital. Nature 387, $253-260$. 
Cowie, Amber. (2011). Biodiversity in the Greenbelt. David Suzuki Foundation and Ontario Nature. Retrieved from: https://ontarionature.org/wp-content/uploads/2017/10/REPORT-GB HabitatDec2011.pdf.

Crooks, K.R. and Sanjayan, M.A. (2006) Connectivity Conservation: Maintaining Connections for Nature. In: Crooks, K.R. and Sanjayan, M., Eds.: Connectivity Conservation, Cambridge University Press, Cambridge.

Crutzen, P.J. (2002). Geology of mankind. Nature, 415, 23.

Deshaies, M.; Boivin, D.; Samson, C.; Brassard, F.; and Charest, R. (2017). Landscape connectivity and integration in protected areas and conservation areas. Discussion Paper prepared for the Pathway to Canada Target One. Retrieved from http://www.conservation2020canada.ca/discussion-papers .

Ducks Unlimited Canada (DUC). (2010). Southern Ontario Wetland Conversion Analysis. Ducks Unlimited Canada. Retrieved from http://www.ducks.ca/assets/2010/10/duc ontariowca optimized.pdf.

Dunn, W. N.. (2012). Public policy analysis: an introduction. Pearson Education Inc., Upper Saddle River, USA.

Environment and Climate Change Canada (ECCC). (2016). 2020 Biodiversity Goals and Targets for Canada. Her Majesty the Queen in Right of Canada. Retrieved from:

http://publications.gc.ca/collections/collection 2016/eccc/CW66-524-2016-eng.pdf .

Environment and Climate Change Canada (ECCC). (2017). Compendium of Canada's Engagement in International Environmental Agreements: Convention of Biological Diversity. Her Majesty the Queen in Right of Canada.

Environment Canada. (2005). Beyond Islands of Green: A Primer for Using Conservation Science to Select and Design Community-based Nature Reserves. Environment Canada: Toronto, ON.

Environment Canada. 2014. Terrestrial Biodiversity of Federal Interest in the Mixedwood Plains Ecozone of Ontario. Environment Canada, Toronto, Ontario.

Environmental Commissioner of Ontario (ECO). (2008). Getting to K(no)w: Annual Report 2007/2008. Environmental Commissioner of Ontario: Toronto.

Environmental Commissioner of Ontario (ECO). (2011). Engaging Solutions: Annual Report 2010/2011. Environmental Commissioner of Ontario: Toronto.

Environmental Commissioner of Ontario (ECO). (2012). Biodiversity: A Nation's Commitment, an Obligation for Ontario. Special Report to the Legislative Assembly of Ontario: Toronto, ON. 
Environmental Commissioner of Ontario (ECO). (2013). Laying Siege to the Last Line of Defence: A Review of Ontario's Weakened Protections for Species at Risk. Special Report to the Legislative Assembly of Ontario: Toronto, ON.

Environmental Commissioner of Ontario (ECO). (2015). Small things matter: Annual report 2014/2015. Environmental Commissioner of Ontario. Toronto: On. Retrieved from: http://docs.assets.eco.on.ca/reports/environmental-protection/2014-2015/2014 2015-AR.pdf.

Environmental Commissioner of Ontario (ECO). (2016). Small Steps Forward: Environmental Protection Report 2015/2016. Environmental Commissioner of Ontario. Toronto: On. Retrieved from: http://docs.assets.eco.on.ca/reports/environmental-protection/2015-2016/EPR-Small-StepsForward Vol2-EN.pdf.

Fahrig, L., \& Rytwinski, T. (2009). Effects of roads on animal abundance: An empirical review and synthesis. Ecology and Society, 14(1), 21.

Forman, R. T. T., \& Alexander, L. E. (1998). Roads and their major ecological effects. Annual Review of Ecology and Systematics, 29(1), 207-231.

Forman, R.T.T., Sperling, D., Bissonette, J.A., Clevenger, A.P., Cutshall, C.D., Dale, V.H.,...Winter, T.C. (2003). Road Ecology: Science and Solutions. Washington D.C., USA: Island Press.

Gray, P.A., D. Paleczny, T.J. Beechey, B. King, M. Wester, R.J. Davidson, S. Janetos, S.B. Feilders, and R.G. Davis. (2009). Ontario's Natural Heritage Areas: Their Description and Relationship to the IUCN Protected Areas Classification System (A Provisional Assessment). Queen's Printer for Ontario, Peterborough, Ontario, Canada. pp356.

Green, B.H. (1996). Countryside Conservation: Landscape ecology, planning and management (3 ${ }^{\text {rd }}$ ed.). E \& FN Spon: London, UK.

Guelph, City of. (2017). Guidelines for the Preparation of Environmental Impact Studies. City of Guelph. Retrieved from: http://guelph.ca/wp-content/uploads/Consolidated-EIS-Guidelines-JUNE-2017.pdf .

Gunson, K., Seburn, D., Kintsch, Crowley, J. (2016). Best Management Practices for Mitigating the Effects of Roads on Amphibians and Reptile Species at Rick in Ontario. Ontario Ministry of Natural Resources and Forestry. Queen's Printer for Ontario: Toronto.

Hack, A. (2018). Getting from here to there - mainstreaming wildlife crossing structures through transdisciplinary design approaches to collaborative planning (Master's Major Research Paper). Ryerson University.

Hadad, N. (December 2015). Corridors for people, corridors for nature: How can the environmental impacts of roads be reduced? Science 350: 6265, p1166. 
Hemson Consulting Ltd. (June 2013). Greater Golden Horseshoe Growth Forecasts to 2041. Accessed from: https://www.hemson.com/wp-content/uploads/2016/03/HEMSON-Greater-Golden-HorseshoeGrowth-Forecasts-to-2041-Technical-Report-Addendum-and-Rev.-Appendix-B-Jun2013.pdf .

Holling, C.S. (1973). Resilience and Stability of Ecological Systems. Annual Review of Ecology and Systematics, Vol 4, 1-23.

Irwin, L. G. (2003). The Policy Analysist's Handbook: Rational Problem Solving in a Political World. New York, NY: M.E. Sharpe, Inc.

Jaeger, J.A.G, J. Bowman, J. Brennan, L. Fahrig, D. Bert, J. Bouchard, N. Charbonneau, K. Frank, B. Gruber, and K. Tluk von Toschanowitz. 2005. Predicting when animal populations are at risk from roads: an interactive model of road avoidance behavior. Ecological Modelling 185,329-348.

Johnson, C.; Balmford, Andrew; Brook, Barry; Buettel, Jessie; Galetti, Mauro; Guangchun, Lei; Wilmshurst, Janet. (April 2017). Biodiversity Losses and conservation responses in the Anthropocene. Science. 356, 270-275.

Keller, I., and C.R. Largiader. 2003. Recent habitat fragmentation caused by major roads leads to reduction of gene flow and loss of genetic variability in ground beetles. Proc. R. Soc. London. B 270:417423.

Kociolek, Angela; Robert Ament; A. Renee Callahan; and Anthony Clevenger. (April 2015). Wildlife Crossing: The new norm for transportation planning. ite Journal. Retrieved from www.ite.org .

Lister, N-M. (2014). Resilience. In Reed, C. \& Lister N-M. (eds). (2014). Projective Ecologies. Harvard University Gaduate School of Design: New York.

Lister, N-M., Brocki, M., Ament, R. (2015). Integrated adaptive design for wildlife movement under climate change. Frontiers in Ecology and the Environment. 13:493-502.

Majchrzak, A., \& Markus, M. L. (2014). Methods for Policy Research: Taking Socially Responsible Action ( $2^{\text {nd }}$ Edition). Thousand Oaks, California: SAGE Publications Inc.

Mark, M. M., \& Henry, G. T. (2011). Methods for Policy-Making a Knowledge Development Evaluations. In Shaw, I.F., Greene, J.C., \& Mark, M. M. (eds), SAGE Handbook of Evaluation. (318 - 339). SAGE Publications Ltd: USA.

McGill, B.; Dornelas, M., Gotelli, N., and Magurran, A. (February 2015). Fifteen forms of biodiversity trend in the Anthropocene. Trends in Ecology \& Evolution. Vol 30, No 2, P104.

Ministry of the Environment, Conservation and Parks (MECP). (2018). Class EA for Municipal Infrastructure Projects [web page]. Retrieved from: https://www.ontario.ca/page/class-ea-municipalinfrastructure-projects. 
Ministry of Municipal Affairs (MMA), Ontario. (2017a). Growth Plan for the Greater Golden Horseshoe (2017). Retrieved from:

http://placestogrow.ca/images/pdfs/ggh2017/en/growth\%20plan\%20\%282017\%29.pdf.

Ministry of Municipal Affairs (MMA), Ontario. (2017b). Greenbelt Plan, 2017. Retrieved from:

http://www.mah.gov.on.ca/AssetFactory.aspx?did=18549.

Ministry of Municipal Affairs (MMA), Ontario. (2017c). Oak Ridges Moraine Conservation Plan, 2017.

Retrieved from: http://www.mah.gov.on.ca/AssetFactory.aspx?did=18548.

Ministry of Municipal Affairs and Housing (MMAH), Ontario. (2014). Provincial Policy Statement, 2014.

Retrieved from: http://www.mah.gov.on.ca/AssetFactory.aspx?did=10463.

Ministry of Municipal Affairs and Housing (MMAH), Ontario. (2018). Citizens' Guides to Land Use Planning. Retrieved from: http://www.mah.gov.on.ca/Page338.aspx.

Ministry of Natural Resources (MNR), Ontario. (2012). Biodiversity It's In Our Nature. Ontario Government Plan to Conserve Biodiversity, 2012 - 2020. Queens Printer for Ontario: Toronto, ON.

Ministry of Natural Resources (MNR), Ontario. (2010). Natural Heritage Reference Manual for the Provincial Policy Statement, 2005 ( $2^{\text {nd }}$ ed.) Queens Printer for Ontario: Toronto.

Ministry of Natural Resources and Forestry (MNRF), Ontario. (2018a). Development and infrastructure projects and endangered or threatened species. Retrieved from:

https://www.ontario.ca/page/development-and-infrastructure-projects-and-endangered-orthreatened-species.

Ministry of Natural Resources and Forestry (MNRF), Ontario. (2018b). Development of the Proposed Regional Natural Heritage System for the Growth Plan for the Greater Golden Horseshoe: Summary of Criteria and Methods. Retrieved from: http://apps.mnr.gov.on.ca/public/files/er/growth-plan-regionalnhs-mapping-summary.pdf.

Ministry of Natural Resources and Forestry (MNRF), Ontario. (2018c). How species at risk are protected [web page]. Retrieved from: https://www.ontario.ca/page/how-species-risk-are-protected.

Ministry of Finance (MOF), Ontario. (2018). Ontario Population Projections Update: Spring 2018 Based on the 2011 Census. Queen's Printer for Ontario.

Ministry of Transportation (MTO), Ontario. (2000). Class Environmental Assessment for Provincial Transportation Facilities. Publications Ontario. Toronto: Ontario.

Ministry of Transportation (MTO), Ontario. (2014). Environmental Protection Requirements for Transportation Planning and Highway Design, Construction, Operation, and Maintenance.

Environmental Policy Office, Ministry of Transportation. St. Catherines, Ontario. 
Ministry of Transportation (MTO), Ontario. (2017a). Environmental Guide for Mitigating Road Impacts to Wildlife: Part of the Environmental Standards and Practices. Environmental Policy Office, Ministry of Transportation. St. Catherines, Ontario.

Ministry of Transportation (MTO), Ontario. (2017b). MTO Best Management Practices for Species at Risk Protection during Maintenance Activities. Environmental Policy Office, Ministry of Transportation. St. Catherines, Ontario.

Ministry of Transportation (MTO), Ontario. (2017c). Road Talk: Ontario's Transportation Technology Transfer Digest. Retrieved from: http://www.mto.gov.on.ca/english/publications/road-talk/road-talk23-summer.shtml.

Municipal Engineers Association (MEA). (2015). Municipal Class Environmental Assessment: Executive Summary. Retrieved from: http://www.municipalclassea.ca/manual/page1.html .

Nagel, S.S. (ed.). (2002). Handbook of public policy evaluation. SAGE Publications Inc.: Thousand Creeks, USA.

National Advisory Panel, The (NAP). (2018). Canada's conservation vision: A report of the national advisory panel. Accessed from:

https://static1.squarespace.com/static/57e007452e69cf9a7af0a033/t/5b23dce1562fa7bac7ea095a/152 9076973600/NAP REPORT EN June+5 ACC.pdf.

Niagara Escarpment Commission (NEC). (2017). Niagara Escarpment Plan, 2017. Retrieved from: https://files.ontario.ca/appendix - niagara escarpment plan 2017 - oc-10262017.pdf.

Noss, R. (1987). Corridors in real landscapes: A reply to Simerloff and Cox. Society for Conservation Biology 1: 2, P159-164.

Ontario Biodiversity Council (OBC). (2011). Ontario's Biodiversity Strategy 2011: Protecting What Sustains Us. Ontario Biodiversity Council: Peterborough, Ontario.

Ontario Biodiversity Council (OBC). 2015. State of Ontario's Biodiversity [web application]. Ontario Biodiversity Council, Peterborough, Ontario. Retrieved from: http://ontariobiodiversitycouncil.ca/sobr.

Ontario Road Ecology Group (OREG). (2010). A Guide to Road Ecology in Ontario. Ontario Road Ecology Group, Toronto Zoo. Prepared for the Environment Canada Habitat Stewardship Program for Species at Risk.

Patton, C. V., Sawicki, D.S., \& Clark, J. J. (2013). Basic Methods of Policy Analysis and Planning (3 ${ }^{\text {rd }}$ Edition). Upper Saddle River, NJ: Pearson Education Inc.

Simberloff, D., Cox, J. (1987). Consequences and Costs of Conservation Corridors. Conservation Biology 1:1, P63- 71 . 
Steffen, W., Grinevald, J., Crutzen, P., McNeill, J. (2011). The Antropocene: conceptual and historical perspectives. Philosophical Transaction of The Royal Society, 369, 842 - 867.

Subsidiary Body on Scientific, Technical and Technological Advice to the UN Convention on Biological Diversity (SBSTTA). (2018). Protected Areas and Other Effective Area-Based Conservation Measures: Draft recommendation submitted by the Chair. Retrieved from: https://www.cbd.int/doc/c/9b1f/759a/dfcee171bd46b06cc91f6a0d/sbstta-22-I-02-en.pdf

Taylor, P. D., Fahrig, L., Henein, K., \& Merriam, G. (1993). Connectivity is a vital element of landscape structure. Oikos, 68(3), 571-573.

Turner, M. G.. (2005). Landscape Ecology: What is the State of Science. Annual Review of Ecology Evolution and Systematics, 36: $319-344$.

United Nations Convention on Biological Diversity (UN CBD). 1992. Convention on Biological Diversity. Retrieved from: https://www.cbd.int/doc/legal/cbd-en.pdf.

United Nations Secretariat of the Convention on Biological Diversity (CBD). (2000). Sustaining life on Earth: How the Convention on Biological Diversity promote nature and human well-being. Secretariat of the Convention on Biological Diversity: Montreal, Canada.

United Nations Secretariat of the Convention on Biological Diversity (UN CBD). (2010). Strategic Plan for Biodiversity 2011 - 2020 and the Aichi Targets: Living in Harmony with Nature. United Nations Environment Program (UNEP): Montreal, Canada.

U.S. Department of Transportation (US DOT). (August 2008). Wildlife-Vehicle Collision Reduction Study: Report to Congress.

Van der Ree, R., Jaeger, J.A.G, van der Grift, E.A. \& Clevenger, A. P. (2011). Effects of roads and traffic on wildlife populations and landscape function: Road ecology is moving toward larger scales. Ecology and Society, 16(1), 1.

Wilcox, B.A., Murphy, D.D. (1985). Conservation Strategy: The Effects of Fragmentation on Extinction. The American Naturalist, 125(6),879-887.

Wise, J., Wynia, M., Bell, A. (2014). Best Practices Guide to Natural Heritage Systems Planning. Ontario Nature. Retrieved from: https://ontarionature.org/wp-content/uploads/2017/10/nhs-guide-web-1.pdf .

World Wildlife Fund International (WWF). (2014). Living Planet Report 2014: Species and spaces, people and places. Retrieved from: http://assets.worldwildlife.org/publications/723/files/original/WWFLPR2014-low res.pdf?1413912230\& ga=2.165705402.583627217.1522625772-992125941.1522625772

Yuan, J.T. (2014). Road Ecology Protocols: Procedures for Incorporating Rad Mitigation Measures into Toronto's Infrastructure Operations (Master's Major Project). York University. 